\title{
Assessing the Resettlement Scheme of the Bui Hydro - Project Using the Social Lens
}

\author{
Richard Twum Barimah Koranteng ${ }^{1,2}$ \& Guoqing Shi ${ }^{2}$ \\ ${ }^{1}$ Volta Basin Development Foundation, Ghana \\ ${ }^{2}$ National Research Centre for Resettlement, Hohai University, China \\ Correspondence: Richard Twum Barimah Koranteng, Hohai University, 8 Focheng West Road, Jiangning \\ District 211100, Nanjing, Jiangsu, China. Tel: 86-150-6224-9514. E-mail: rtwumus@yahoo.com
}

Received: March 14, 2018

doi:10.5539/jsd.v11n4p288
Accepted: May 25, $2018 \quad$ Online Published: July 29, 2018

URL: https://doi.org/10.5539/jsd.v11n4p288

\begin{abstract}
With particular reference to the Bui dam, irrespective of the achievements chalked in executing certain perspectives of the Resettlement Planning Framework, vis-à-vis the fulfilment of some promises, these achievements are not tenable (unceasing) in view of the fact that the sustained prevalence of these facilities is heavily reliant on the folks' sustenance which is non-existent and far-fetched. The main rationale of this paper is to assess the resettlement scheme of the Bui hydro project using the social lens. That notwithstanding, the study identified the key attributes of effective resettlement plan, determined the distinctive social implications of resettlement schemes on displaced individuals caused by dam construction, as well as investigated the critical socio-cultural issues associated with resettlement schemes in Ghana, specifically using Bui Power Authority (BPA) and Gyama New Settlement Township (BPAGs) as the case study organization and locality respectively. Purposive sampling using questionnaire instrumentation was used to collect data from the staff/resettlers of the organization and locality under scrutiny. A 5-Point Likert scale which was later transformed into the Relative Importance Index (RII) was used to identify the key attributes of effective resettlement plan, determine the distinctive social implications of resettlement schemes on displaced individuals caused by dam construction, as well as investigate the critical socio-cultural issues associated with resettlement schemes at BPAGs. The results indicated the 6 key attributes of effective resettlement plan in Ghana as: sustainable and effective compensation framework, effective participation of APs, thorough description of resettlement assistance and restoration of livelihood activities, consideration of short and long term strategies/government responsibility of APs' rights, strict adherence to monitoring and evaluation regimes, in addition to clarity of definition in terms of entitlements, eligibility, ethnicity, etc. Secondly, with respect to the distinctive social implications of resettlement schemes on displaced individuals caused by dam construction, participants at BPAGs intimated the following parameters: loss of asset that supports community livelihoods, economic upheavals, adverse health implications for communities, loss of cultural identity, adverse impact of conservation efforts (ancestral heritage sites), including shift in social roles. Furthermore, the critical socio-cultural issues associated with resettlement schemes in Ghana as revealed by the respondents' were as follows: social or psychological marginality, social disarticulation/social costs, depreciation of ethnic group's social status, dispersion and fragmentation of existing communities, education loss as a distinctive and additional risk, as well as loss of control over physical space of APs. It is recommended that stakeholders, project developers, economies across the globe inculcate these strategic initiatives: Avoidance or minimization of involuntary resettlement, reconceptualization of resettlement programs, encouragement of community participation, and effective compensation packages should be given the needed precedence, etc. so as to manage the issues identified.
\end{abstract}

Keywords: resettlement, scheme, Bui Dam, scheme, hydro-project, social lens

\section{Introduction}

\subsection{Background of the Study}

Undisputedly, resettlement projects worldwide poses uncompromising repercussions on the sustenance of intrinsically deranged individuals. These repercussions encompasses straightforward derangement, flooding of upscale lands for agricultural purposes, hamlets and eatery surfaces, river beds' deposition, soil degeneration, extinct freshwater dwelling; vector borne maladies transmission like bilharzia, physical or mental pressure and 
trauma, abysmal authority and managerial routines, native purification; and inaccessibility to land and resources at the current place of abode (Lund, 2009). Over the past few decades, indigenous localities have been saddled with the repercussions encompassing infrastructural advancement institutionalization like dams, agric-oriented projects, state recreational area, megalopolitan and non-rural augmentation. Albeit, these advancement-oriented projects are touted to be of state preference, they have constant agitation and bickering among indigenous localities for land accessibility and its associated resources to a varying degree (Miine, 2014). Infrastructural projects that are advancement-oriented, and interconnected advancement endeavours happen to be one of the pivotal origins of surrounding (scenery) issues, thus exemplifying a peril of communal pandemonium and agitation. For example, in relation to the Brazilian perspective, neighbourhood lobbyists established the provincial delegation against mega dams, which served as proof to individuals troubled by expatriation (Cernea \& Guggenheim, 1993).

A semi-occasional pledges and constitutional regulations have been developed and executed to safeguard advancement-enforced troubled individuals. These regulations are easily accessible within the universal civil liberty codes and pre-emptive (privileges) under the household judiciary process if the country is a testifier to universal civil liberty codes. In effect, when the state shies away from safeguarding implementation, it signifies that the government has turned a blind eye to the predicament of the subjugated populace, attributable to lineal prejudice (bigotry) just to mention a few. This scenario do crop up because pressurized re-locators more often than not remain domiciled in their native country. In view of this, their constitutional safeguarding regimes should be made certain by the state from the theoretical perspective. That notwithstanding, the same state are supposed to be custodians of their derangement-related issues (Pankhurst \& Piguet 2009). Hence, Lund (2009), do advocate for a glaring disparity to be effectuated between the deserter dynasty and scenarios underpinning derangement, specifically when the derangement is necessitated by projects that are advancement oriented. Pressurized expatriation is an enigmatic domain of scholarly investigation that mostly integrates governmental, physical and advancement derangement study (De Wet, 2006; De Wet, 2004). The research schools of thought between the deserters' learning and coerced expatriation leaves much to be desired. As per the argument of Lund (2009), projects relating to dam's construction have succeeded in deranging individuals more than 60 years ago by rebuilding after the $2^{\text {nd }}$ World War in developed economies across the globe. Synonymously, contemporary autonomous economies like Ghana was bedevilled with advancement-oriented derangement. Albeit, over the erstwhile two decades, the extent of pressurized derangements triggered by advancement projects plummeted to ten million individuals annually or some two hundred million individuals across the globe (Cernea, 2004).

Resettlement guidelines and policies in myriads of economies, states and multilateral corporate entities, have been formulated with the rationale of curtailing the excesses associated with the efficient functioning of resettlement schemes and subsequently, decimating the population dynamics of displaced individuals across the globe (De Wet, 2006). From the global perspective, China has been identified as having the largest portion of development induced displacement projects. For example, the 3 gorges dam happens to be the most gigantic hydroelectric power project that deranged more than 1,200,000 populace from thirteen cities, one hundred and forty towns, in addition to one thousand, three hundred and fifty villages. Furthermore, the length of the reservoir stretches more than six hundred kilometre

According to Lund (2009), it is estimated that the sum total of folks deranged by dam constructional projects, with Bui dam inclusive in Ghana is about one hundred million, two hundred and sixteen thousand. From the Ghanaian context, the crippling issues encompassing the sustainability of dam resettlement gained prominence during the construction of the Akosombo dam about five decades ago. This, inadvertently created the exigent need for quite a sizable plethora of indigenes within the catchment area, including suburbs of the Kete Krachie, Afram Plains and the Akosombo Municipality, to be relocated (Miine, 2014). Inadvertently, miscellaneous homogeneous project like the Bui dam construction surfaced with expatriation accoutrements for the troubled localities. With particular reference to the Bui resettlement scheme, eight localities with a population density of 1 , 216 individuals were relocated (BPA, 2008).

Interestingly, these intervention mechanisms put in place with the rationale of putting smiles on the faces (improvement in living standards) of the displaced individuals within the frontiers of Bui geographical locality is plagued with myriads of social retrogressive and crippling factors like homelessness, food insecurity, social disarticulation, loss of control of physical space, increased morbidity/mortality caused by the stress and the environmental change of movement, dispersion and fragmentation of existing communities (Mettle, 2011, Tetteh, 2012, Koenig, 2001; De Wet, 2006, De Wet, 2009).

It is worth noting that the sustainability of the countless number of resettlement schemes across the globe has one indispensable rationale of re-establishing troubled indigenes swiftly into their archaic sustenance way of 
living relating to communal, ethnic, monetary and environmental perspectives, and preferably, more enhanced and perpetual scenarios. The attainment of this rationale is associated with definite and indefinite encumbrances that crops up owing to the acquisition of land, indemnity and infusing re-locators into their upgraded place of abode through locality involvement. During the process, accommodation, locality edifices and processes, communal connections, and serviceabilities could be compromised as exemplified by Akosombo and the Kpong expatriation codification (Raschid-Sally, Akoto-Danso, Kalitsi, Ofori \& Koranteng, 2008).

It is against this background that the researcher seeks to identify the key attributes of effective resettlement plans, determine the distinctive social implications of resettlement schemes on displaced individuals caused by dam construction in Ghana. The study will also proceed to investigate the critical socio-cultural issues associated with resettlement schemes in Ghana, with special emphasis on Bui Power Authority (BPA) and Gyama New Settlement Township in the Brong Ahafo precinct of Ghana.

\subsection{Problem Statement}

Ghana's historical perspective on the building of dams to serve as an artificial means of making water available to crops on agricultural lands, in addition to HEP could be foot-printed to the early parts of the sixties with countless number of dams being erected for electrical supply and irrigation reasons. Regardless, it was only with Akosombo Dam erection that the incessant social bottlenecks (marginalization, social disarticulation, increased morbidity/mortality rates, homeless, food insecurity, etc.) militating against the smooth functioning of resettlement schemes cropped up. The dam construction was supposed to have taken care of about eighty thousand deranged individuals, but currently after half a century after its construction, there appears to deficits with respect to putting a perpetual and feasible strategic initiatives in place to totally eliminated, and if possible, manage it to an acceptable threshold levels (imperishability of the resettlement scheme) (Raschid-Sally et al., 2008). Considering the experience emanating from the Akosombo resettlement project among others, it is expected that the Bui resettlement project provide a replacements for the individuals within its catchment domains and its environs, vis-a-vis ensuring a continuity between family lineages. This would invariably help address bottlenecks associated with the persistent and potential environmental challenges, with much emphasis on the socio-cultural dimensions of the victims' lives within the jurisdiction of Bui dam (social perspective). To add to this, Cernea (1999) submits that expatriation culminates into deficiency of lands, subjugation, lack of food security, augmented death rate, inaccessibility to hackneyed asset and communal non vocalization. Expatriation blueprints could be evaluated vividly in relation to these communal and monetary systems, acquisition of land, climatic conditions, framework and governmental landscape in which they exist (Oberai, 1992). Also, the construction of the Bui dam has led to myriads of societal enigmas such as the inundation of approximately $25 \%$ of Bui State Meadow, derangement of 7 localities, and the extermination of indispensable flora and fauna varieties among others (Ofori-Amanfo, 2005; ERM, 2007; IUCN, 2010; Ghana News Agency, 2012; Miine, 2014).

That notwithstanding, Olawepo (1997) opined that the Kainji expatriation blueprint from the Nigerian perspective was undoubtedly one of the notable positive strides that occurred in Sub Sahara African economies because it helped immensely in improving the living standards of the re-locators comparatively. He was of the strongest conviction that the expatriation brought about communal frameworks, community advancement and fraternization. This presupposes that if expatriation are judiciously programmed and effectuated, it invariably produces some merits to the locality been relocated.

It is worth noting that past and previous research projects that highlight on assessing the resettlement scheme of the Bui Hydroelectric project from the social perspective domain only (social lens) in Ghana, specifically using both BPA authority as well as resettlement communities (Gyama New Settlement Townships) allotted for the displaced individuals within the confines of Bui dam appears to be non-existent, unexploited and under-researched. Strictly speaking, research works that seeks to identify the key attributes of effective resettlement plan, determine the distinctive social implications of resettlement schemes on displaced individuals caused by dam construction as well as investigate the critical socio-cultural issues associated with resettlement schemes in Ghana with special emphasis on BPA via the resettlers at Gyama New Settlement Township appears to be like a drop in the ocean.

Furthermore, from a critical appraisal of related literature suggest quite a sizable plethora of extensive research projects embarked upon that relates to resettlements in Ghana and the world in its entirety but absolutely not the topic under scrutiny. However, the researcher's chosen topic is yet to be extensively subjected to any rigorous empirical assessment especially in many developing countries including Ghana (a void or research gap that needs to be filled). 
This study therefore seeks to capitalize on these research gaps and proceed to identify to identify the key attributes of effective resettlement plan, determine the distinctive social implications of resettlement schemes on displaced individuals caused by dam construction as well as investigate the critical socio-cultural issues associated with resettlement schemes in Ghana with special emphasis on BPA via the resettlers at Gyama New Settlement Township.

\subsection{Aim and Objectives of the Study}

The main objective of this study is to assess the resettlement scheme of the Bui hydroelectric project from the social perspective domain in Ghana through a survey. The specific objective are:

1) To identify the key attributes of effective resettlement plan in Ghana.

2) To determine the distinctive social implications of resettlement schemes on displaced individuals caused by dam construction in Ghana.

3) To investigate the critical socio-cultural issues associated with resettlement schemes in Ghana.

4) To proffer strategic initiatives to manage the critical socio-cultural issues associated with resettlement schemes in Ghana.

\subsection{Research Questions}

Arising from the problem statement, the under-listed research questions are of immense relevance to the study:

1) What are the key attributes of effective resettlement plan in Ghana?

2) What are the distinctive socio implications of resettlement schemes on displaced individuals in Ghana?

3) What are the critical socio-cultural issues associated with resettlement schemes in Ghana?

4) What strategic initiatives should be put in place to manage the critical socio-cultural issues associated with resettlement schemes in Ghana?

\subsection{Significance of the Study}

Contemporarily, resettlement schemes emanating from dam construction and its associated social bottlenecks are indispensable as far as the sustenance of such project set-ups across the globe is concerned. The hallmark of every resettlement regime is to titivate the teeming APs so as to ensure that their standard way of living is not compromised during post project completion stage within any stipulated time period (WCD, 2000). It is worth noting that more often than not, the indigenes afflicted in the expatriation booty of the Bui dam enormously is embedded within the destitution classification. In view of this, it is therefore imperative that any advancement-oriented strategic mechanisms ceases to further deplete (exhaust) them or aggravate their standard of living in the foreseeable future (futuristic view) in tandem with the tenets captured in the Resettlement Planning Framework of Bui dam (Sutcliffe, 2009; Tetteh, 2012; Arthur, 2016). These circumstances need to be considered a nip in the bud so as to make certain that the imperishability of any expatriation blueprint, specifically Bui expatriation blueprint lives up to its billing.

Furthermore, there is the exigent need to tentatively evaluate the imperishability of the Bui expatriation project in order to create some threshold of awareness (sensitization, advocacy, etc.) for policy makers so they can be abreast with its excesses and pitfalls and subsequently map out strategic initiatives to manage it to the barest minimum or acceptable threshold levels.

The achievement of any expatriation regime has the propensity to service as the basis for futuristic advancement purpose within the locality and beyond. Again, it is to make certain that APs within countless number of communities plagued by dam construction like Bui are adequately prepared for preventive mechanisms against socio-cultural issues associated with resettlement schemes of the Bui Dam, etc. as and when the need arises.

Lastly, the study would provide ground rules and policy lessons for the top echelons in Ghana, in addition to planners to judiciously consider not only the environmental and economic aspects of APs but also, the socio-cultural needs of displaced individuals and ensure that subsequent developmental project stand tall in the midst of encumbrances militating the effective functioning of resettlement schemes in Ghana and the world in its entirety.

\subsection{Scope and Limitations of the Study}

The study is limited to the Bui Power Authority (BPA) and Gyama New Settlement Township and may not connote the generalizability with respect to the topic under scrutiny. That is to say, the study may not be representative of the entire country (Ghana). 


\subsection{Organization of the Study}

This study is structured into five chapters. A concise description of details pertaining to each chapter is summarized below: Chapter one introduces the topic under review by taking into consideration the study's background, enigma statement, justification, questions to be researched, delimitation, limitations, in addition to the organization of the study. Chapter two highlights on the various concepts, theories and related literature of the topic under study. It presented empirical literature in the form of previous research works and related literature undertaken on the subject matter under study. It also highlighted judgments by other researchers in order to provide a basis to either affirm or refute such judgments. Chapter three mainly elaborated on the research methodological processes. Chapter four accentuates on the data presentation and detailed discussions of the results obtained. Finally, chapter five provided summaries of the study's results and explained any conclusion resulting from the statistical analysis of the data. It clarified any deficiency of the research topic and offered recommendations. It also suggested other areas requiring further studies.

\section{Literature Review}

\subsection{Preview}

This chapter takes a tentative scrutiny of the authoritative works of various authors which are most relevant to resettlement schemes across the globe. This literature review focuses on the discussions that relates to theoretical and empirical development underpinning previous and past research projects (works) that pertains to resettlement schemes in Ghana and the world in its entirety.

\subsection{Concept and Meaning of Resettlement (Expatriation) Schemes}

Globally, expatriation blueprint have been executed for myriads of reasons. Strictly speaking, these schemes are put in place with the ultimate rationale of triggering the execution of a non-urban advancement code like modernistic roads, building of dams, in addition to land ownership remodeling effectuation, agriculture productivity optimization, the protection of flora and fauna species, and the conservancy and profiteering of lumber natural resources (Evrard \& Goudineau, 2004). Woldeselassie (2002) defines expatriation as the migration of localities from one milieu to the other, and alterations or rectifications of the tangible and communal milieu in which re-locators are confronted with and gets acclimatized. He proceeded to further elucidate its conceptualization as myriads of movement categories. As captured the UNHCR (2011) report, the terminology "resettlement" connotes the assortment and movement of deserters from a geographical precinct in which they have yearned for safeguarding to a $3^{\text {rd }}$ territory which has concurred to take them on as deserters with perpetual uptown position.

\subsection{Displacement (Derangement) Relating to Communal and Monetary Debilitation}

Contemporarily, in order to swerve the hazards encompassing the derangement regimes, it is expedient for an individual to be hugely reliant on theories that has the ability to elucidate how it may culminate into communal and monetary debilitation. In view of this, there exist at least two schools of thought as to why expatriation and derangement projects fails to live up to their billing. As ascribed to the assertion of De Wet (1996), these debilitating tendencies may be referred to as the "insufficient submissions" and the 'ingrained sophistication' strategies respectively.

\subsection{Impoverishment, Risks and Reconstruction (IRR) Model}

More often than not, in scenarios where individuals relocate to new localities, they are bedeviled with myriads of encumbrances as far as getting acclimatized to their new habitat's prevailing conditions is concerned. The special eco-friendly, communal, monetary and ethnocentric scenarios in which they have to get acclimatized demand different adjusting techniques. Under normal circumstances, this acclimatization is such an extremely arduous and herculean task and is associated with myriads of hazards. Cernea (1996) contends that, in order to circumvent and strategically manage these hazards to a varying threshold, the fishing out, in addition to the effective utilization of a feasible conceptual framework cannot be overemphasized. He has invariably propounded an "IRR" model to titivate the evaluation and prognostication of hazards in tandem with involuntary derangement (cernea, 2005).

\subsection{Complexities Underpinning Resettlement}

The "intrinsically sophisticated" strategy perceives expatriation as an intriguing and troublesome endeavour from naturalistic perspective. The incessant compromise encompassing programmed expatriation more importantly emanates from the special attributes that pertains to forced expatriation as an advancement code (Tadesse, 2009). Table 1 depicts the villages, communities and districts deprived of lands and natural resources 
due to the construction of the Bui dam.

Table 1. Villages deprived of lands and natural resources due to Bui Dam construction

\begin{tabular}{|c|c|c|c|}
\hline \multirow[t]{2}{*}{ Construction Activity } & \multicolumn{2}{|c|}{ Village/Community/District } & \multirow{2}{*}{$\begin{array}{l}\text { Risk and Effect } \\
\text { Threshold of Dam }\end{array}$} \\
\hline & Banda & Bole & \\
\hline $\begin{array}{l}2 \text { saddle dams and camp } \\
\text { construction site }\end{array}$ & Bungase & - & Major \\
\hline Quarries & $\begin{array}{c}\text { Bungase and Banda } \\
\text { Ahenkro }\end{array}$ & - & Minor \\
\hline Road upgrading & - & $\begin{array}{l}\text { Bamboi, Banda, } \\
\text { Nkwanta, Teselima, } \\
\text { Carpenter, Gyama }\end{array}$ & Minor - Negligible \\
\hline Transmission line & Gyama and Teselima & - & Moderate \\
\hline $\begin{array}{l}\text { Creation of reservoir } \\
\text { (total inundation) }\end{array}$ & $\begin{array}{c}\text { Bui, Bator, Dam site, } \\
\text { Dokokyina }\end{array}$ & $\begin{array}{c}\text { Lucene, Agbegikro, } \\
\text { Brewohodi }\end{array}$ & Major \\
\hline $\begin{array}{l}\text { Creation of reservoir } \\
\text { (inundation of forest and } \\
\text { farmlands only) }\end{array}$ & $\begin{array}{c}\text { Banda Ahenkro and } \\
\text { Bungase }\end{array}$ & $\begin{array}{c}\text { Banda Nkwanta and } \\
\text { Gyama }\end{array}$ & Major \\
\hline
\end{tabular}

Source: ERM (2007) and Tain District Assembly (2012)

Table 2 accentuates on the number of villages displaced by Bui dam construction.

Table 2. Number of villages displaced by Bui Dam construction

\begin{tabular}{|c|c|c|}
\hline Village & Population & Number of Households \\
\hline Bator & 437 & 63 \\
\hline Bui & 297 & 42 \\
\hline Dam site & 36 & 6 \\
\hline Brewohodi & 48 & 10 \\
\hline Lucena/Loga & 26 & 4 \\
\hline Agbegikro & 107 & 22 \\
\hline Dokokyina & 165 & 36 \\
\hline Total & 1,116 & 183 \\
\hline
\end{tabular}

Source: ERM (2007)

It is worth noting that the creation of Bui Lake and the attendant loss of lands to inundation have resulted in absolute sustenance disappearance and stationary properties belonging to 7 localities as captured by table 2 above.

According to ERM (2007), communities such as Bongaase, Banda Nkwanta, and Gyama were perpetually denied their lands, crops that had been propagated, as well as forest to the lake creation. Dokokyina was not inundated, but had to be re-established in view of the fact that the locality was to be encapsulated by the dam towards the 4 cardinal points, and therefore totally cut off from access routes in Ghana. Such a community, if not relocated, would have been accessible only through Cote d'Ivoire. Meanwhile, a number of households in the Dokokyina village refused to relocate based on the findings of Arthur (2016), and were living in makeshift shelters in the area of the old village.

Generally speaking, cash compensations were provided by BPA for people who lost property to the Bui Dam 
construction. For example, re-locators were financially remunerated, including expatriation cash reserve of fifty Ghana Cedis relief to commence a another farm, and a monthly support cash reserve of hundred Ghana Cedis given to every housing outfit annually (BPA, 2011), as compared to national monthly minimum wage of GHS 83.97 for 2010. The cash disbursement was intended to trigger monetary insulation for the re-locators based on the premise that getting to the tail end of the $1^{\text {st }}$ year, they would be gifted with extra imperishable money-producing fountainheads; albeit, these reimbursements were contended to be inadequate for its intended reasons.

Some communities in the Bole district were also been affected by the Bui dam construction. Communities such as Dam Site, Brewohodi, Lucene/Loga, and Jama (Gyama) have been flooded by the Bui dam, and consequently relocated in the Jama/Gyama resettlement camp. Other communities in the Bole District have been affected through loss of land and other community resources to the construction of saddle dams, road upgrading, and inundation of forests and farmlands (refer to table 1 cited earlier).

\subsection{Essential Attributes of Effective Resettlement Scheme Worldwide}

In scenarios involving expatriation, the local populace are normally denied accessibility to lands, housing outfits, trees of optimum economic value, natural resources, in addition to miscellaneous properties among others. In effect, the re-locators reconstructed their earnings and monetary properties at locations extremely far from their former localities. This calls for optimum preparation, effectuation and estimation of expatriation blueprint (ADB, 2010). In allusion to the postulate of Cernea (2000), a superior quality expatriation strategy should entail state answerability of deranged individuals' privileges, safeguarding of anchors' population dynamics or locality curiosity, and milieu safeguarding. He argued that although these infrastructures are operational requirements for enhanced expatriation endeavours, quite a sizable plethora of developing economies, with Sub Saharan Africa are devoid of ground rules, expertise deficiency, as well as policy inadequacies adversely militate against its effective execution to a significant extent.

Expatriation strategies (ESs) should therefore be able to delineate in simplistic specifications privileges and acceptability of deranged and troubled individuals (ABD, 2010). "ESs" should take cognizance of short-lived and perpetual monetary initiatives for deranged folks (ADB, 2010). Monitoring and evaluation (M \& E) are indispensable and strategic accoutrements in expatriation preparation and effectuation. Monitoring in this perspective encompasses a sustained system relating to the gathering, assessing and publicizing the positive strides underpinning expatriation operations with the ultimate rational of making information available for acclimatization and enhanced execution of the expatriation blueprint. Evaluation entails a systematic mechanism of predicting aftermaths with stated purposes or as captured in the superior quality strategy relating to expatriation regime APs (UNHCR, 2004; ADB, 2010). Moreover, the preparation and execution of expatriations could chalk optimum success rate if precedence is accorded to sufficient cash reserves and skilled workers. Optimum involvement of troubled folks in the preparation and execution regimes that pertains to expatriation blueprint cannot be overemphasized (Miine, 2014; ADB, 2010, Sutcliffe, 2009). "ESs" should also be able to delineate in simplistic terms, the distinct ethnocentric, and governmental attributes of the troubled folks and this requires skilled personnel or expertise (Cernea, 2000).

The Global Finance Organization publication for developing an Expatriation Activity Strategy also postulates the under-listed processes underpinning the relocation of deranged folk as a result of dam construction. These are spelt out as follows:

$>$ Fishing out of endeavours eventualities and troubled populace;

$>$ Constitutional infrastructure for the acquisition of land, in addition to indemnity;

$>$ Indemnity infrastructure;

$>$ Characterization of expatriation help and rejuvenation of sustenance operations;

$>$ Tentative financial plan;

$>$ Execution timetable (itinerary);

$>$ characterization of firm's roles;

$>$ Infrastructure for general buzz session, involvement, and advancement preparation;

$>$ Characterization of avenues for reparation of complaints; and

$>$ Infrastructure for $\mathrm{M} \& \mathrm{E}$, in addition to publicizing.

With respect to the diverse forms of resettlement planning processes elaborated on in this subsection, it is so 
glaring that the significant additions of diverse collaborators in the preparation regime is indispensable. One striking attribute prevalent in this perspective relates to the tendency to habitually oversee the preparatory regime to ensure the attainment of the set targets or objectives. Any attempt to turn a blind eye to this regime may culminate into expatriation debacle in the foreseeable future (futuristic perspective).

\subsection{Social Implications of Resettlement Schemes on Displaced Individuals Caused by Dam Construction}

Resettlement is often considered to be a negative consequence of dam construction, including loss of infrastructure, monetary debacle, disappearance of ethnocentric individuality, diversions in communal duties, and property deprivation that backs locality sustenance (Egre, 2007; Bennett \& McDowell, 2012; Biswas, 2012; Peter, 2013; Fratkin, 2014). Coercive eviction of people, such as those relating to land disputes, can adversely affect community assets, as happened in the case of resettlement of some communities in Phnom Penh, Cambodia (Cave et al., 2010). However, resettlement can also result in positive outcomes, such as improved housing and educational enhancement.

Bennet and McDonald (2012) defines the terminology "Resettlement" as the abrupt and unwavering expulsion from what is well-known to a dissimilar settlement, which at times devastates communal connections, and aggravate hazards associated with the troubled individuals. To add to this, Bartolomé et al., (2000) also suggest that expatriation epitomizes the coercive re-establishment of individual from one geographical precinct to the other. Dams' erection may culminate into expatriation of localities, and the destitution of people's access to natural resources and properties like agricultural lands, roads, health posts, and educational edifices (Gordon \& Amatekpor, 1999; Andam et al., 2010; Ferraro et al., 2011; UNDP, 2011a; International Rivers, 2011, 2013).

Pertaining to expatriation-inclined coerced land acquirement, localities can feel the pinch through lands for farming deprivation, and profit generation (Syagga \& Olima, 1996; Han \& Vu, 2009). Abbink (2012) argues that the HEP erection can have significant implications on the surroundings, communal, monetary systems, sustenance, and the communal configuration and ethnicity of the folks living few kilometres away from the dam or posterior stream. The Akosombo Dam project in Ghana, for instance, culminated into locality shrines disappearance, ancestral churchly terraces like holy thickets, and also led to crucial physical and mental wellness repercussions for quite a handful of localities close-by (Kalitsi, 2004; Dzodzi, 2006). More so, the construction of the Akosombo Dam reservoir led to a surge in some aquati-related maladies like schistosomiasis, and malaria among others. That notwithstanding, it also culminated into decimating the population dynamics of other diseases, like the one whose causative agent is popularly referred to as "onchocerca', in some localities close to where the dam is cited (Kalitsi, 2004).

Some schools of thought are of the notion that the inability to prognosticate such negative repercussions pertaining to the erection of Akosombo Dam makes it extremely laborious for a detailed expatriation blueprint to be prepared and executed to curb its negative implications, like the expected communal and health impacts (Lerer \& Scudder, 2005). Some resettlement pundits have postulated that the communal tariff underpinning the erection of mega dams fails to really monetary sense as far as their construction is concerned (Ansar et al., 2014). The actual costs of HEP enormous project advancement dam erection can have a negative repercussion on conservancy strides like the establishment of safeguarded domains (ERM, 2007). For example, Bui Dam culminated into the disembalming and re-tombing of some forefathers interred in the localities. That notwithstanding, forefathers ancestry locations, and locality historical or notable sights for the communities of Bator Akaiyakrom, Bui, and Dokokyina remained un-retrievable (ERM, 2007; Ghana News Agency, 2012).

Although these forefathers have been re-interred, there is still absence of scheme to develop an efficient framework, like tombstone, to protect the nobility of the forefathers. Again, the Bui Dam erection also translated into the disappearance of visitor privileges to the recreational area, which in 2008 amounted to two hundred and eighty (Jachmann et al., 2011). The repercussions for the foreigner privileges disappearance equates to a diminished earnings affiliated to the recreational area. Resettled communities also face additional challenges, as illustrated by the Akosombo Dam construction in Ghana. Here the Volta River Authority (an outfit mandated by the Ghanaian Government to reconcile and keep close tabs on the Akosombo Dam project) established an Expatriation Outfit to strategize and effectuate the program to sort out for folks who would be deranged by the fast approaching Volta inundations (Dzodzi, 2006). However, the process of the resettlement was impeded, in part, by the delay in establishing the government machinery to execute the project (Kalitsi, 2004).

Furthermore, the process of evacuation and relocation of communities' cut-off by the Akosombo Dam was stalled by the fact that some affected communities also located along the edge of the Volta Lake could only be accessed by boats, and in some cases neither by road nor water. For many resettlements, inefficient indemnity interventions, and productive lands deprivation, and sustenance options weaken the intransigence of localities to 
the implications (Ding, 2007; Ty et al., 2013). In the case of the Akosombo Dam construction, evaluators establishing compensation entitlements did not value land, but allowed individual claimants to seek compensation by establishing their rights to their lands at the Lands Department (Kalitsi, 2004).

The cumbersome nature of the valuation, as well as some teething challenges associated with institutional bureaucracies, resulted in the inability of some affected communities to receive appropriate compensation. Resettlement of communities after dam construction can be positive when it incorporates an effective compensation program, including the payment of appropriate and realistic compensation packages, provision of alternative housing units, and effective planning to uphold or provide livelihood opportunities for dam-affected communities (Marfo, 2014; Bennett \& McDowell, 2012). For example, the Akosombo Dam resettlement process focused on key guiding principles and policies to mitigate the potential effects of relocation on the livelihoods of affected people (Kalitsi, 2004).

Key amongst the policies is the use of the resettlement as a privilege to optimize the communal and fiscal condition of the individuals, and the provision of cash compensation for those who opted to receive cash rather than re-establishing themselves, or being expatriated, that is getting indemnity in kind, specifically collaborating with a centrally prepared expatriation endeavour (Kalitsi, 2004). In other resettlement situations, such as the Bui resettlement process, key policies such as the improvement of the agricultural system from subsistence to cash economy was, in principle, paramount (ERM, 2007). In the Bui resettlement process, people who opted to build or expand their houses could only do so after evacuation to a settlement of choice and an allocation of a resettlement house as compensation in kind. For example, BPA for some years in advance disallowed people from modifying their homes in the villages slated for resettlement (Arthur, 2016).

Therefore it is important to reiterate that compensation principles and policies need to be geared towards mitigating the effects of dams, and providing opportunities to enhance livelihood opportunities available to the affected people. For example, plans to construct dams should first address the potential effects of the dam on nearby communities such that people's concerns including livelihoods would be secured before the potential effects are felt (Mettle, 2011; De Wet, 2006; Arthur, 2016; Sutcliffe, 2009). People could be resettled earlier and allowed to readjust to livelihoods in their new communities well ahead of the impoundment of the dam and resultant flooding phases of the dam construction. In the case of the Bui Dam construction, communities were made to face effects such as flooding of farmlands, and to relocate to new settlements in which some structures, such a clinics, community centre, and schools, were not yet completed. Resettlement programs have not always been effective, due to the failure to incorporate the concerns of the communities into the overall resettlement process, including the location of new resettlements, design and construction of new structures, changes in livelihoods, and plans to minimize the adverse effects of the intended dam construction (Arthur, 2016).

\subsection{Socio-Cultural Issues Pertaining to Resettlement Schemes across the Globe}

Basically, humans cannot be considered as separate monetary entities, but rather forms part of communal and ethnocentric processes that contribute immensely to their sustenance and existence. When derangement enervates or incapacitates pivotal communal connections and endurance strategies, indigenous command processes breaks down and some factions get exhausted as far as their self-management regimes is concerned (Downing, 1996). This gives rise to communal disarticulation (clarity deficits), as well as segregation of existing communities. The disappearance of exchange connections and resulting communal synergy can also enhance power deficiency, reliance, and susceptibility (Cernea, 2000). Communal disarticulation is especially prevalent when existing social factions have issues resettling in unison, but may also take place even when factions are well-knitted together and stay in close association, but lose their tendency to function efficaciously in the contextual perspective of upgraded communal and governmental forces. Subjugation (marginalization) is perceived by phenomenal sustainable development essayists like De Wet (2006), Kyei-Dompreh (2012) and Cernea (2000) as a predominantly single process and takes place when family relations of folks are deprived of fiscal strength and become subjected to descending transportability. This may be attributable to their inability to effectively utilize their obsolete ingenuity at a new locality, and finding their already existing human resources old-fashioned. Expatriation may give rise to the disappearance of control relating to tangible space (vacuum) (Oliver-Smith, 1996; Arthur, 2016; Miine, 2014; WCD, 2000a), in addition to a new surrounding in which erstwhile knowledgeability and skillset, either singly or communal, are less productive (Downing, 1996). Monetary (economic) subjugation (marginality) could culminate in turn to communal or cognitive subjugation, like communal position depreciation or affective enigmas (Cernea, 2000). It is also possible for whole ethnocentric factions to nosedive on their communal rank as they become imbibed into states at the tail end of a country's lamination processes (De Wet, 2006; Koenig, 2001; Mettle, 2011; Tetteh, 2012; Raschid-Sally et al., 2008). 
The tendency of indigenous factions to rely on expatriation to augment their dominance has been extremely enigmatic, in view of the fact that they normally rub shoulders against each other so as to maintain what they already possess. Deficiencies pertaining to the propensity to sustain this dominance, already prevailing indigenous chieftains can often culminate into the eroding of credibility (Scudder, 1996). Albeit, it is not only the power distribution existing between the deranged and the society as a whole that presents alternatives for alterations, but also the dispersion within the deranged locality. Myriads of preferences often surface among those re-established, as some of them will not want to rebuild localities that failed to work in accordance with their interest.

Pertaining to rebuilding as communal units, this signifies that some factions will shy away from reconstruction of the units, in addition to forms of communal union that failed to recognize them. This was exemplified in certain Indian resettlement scenarios where down social class preferred to relocate apart from upper counterparts (villagers) with whom they had some years back resided with (Mahapatra, 1999) and at Manantali (Mali), where small villages opted to regroup in mega folds so they could effectively compete with neighbouring hamlets for position and authority (control).

Differing preferences existing between male and female, in addition to the inexperience and matured individuals are also rampant. The disappearance of communal and ethnic resources, albeit, is not only enigmatic with monetary repercussions, but also an indispensable communal deficit within just to mention a few. An instrumental part of mortal ethnicity is glued to prevalent interpretations of time and space, in addition to the manner ways in which they are accorded the requisite attention; public often structure themselves intrinsically through their linkage to space (Downing, 1996); expatriation antagonizes this pattern. The devastation of the indigenous monetary pattern may not necessarily be the ultimate rationale for social disarticulation, since signage of communal anarchy more often than rear its ugly head before fruitful operations' disappearance, as folks commences action in tandem with the futuristic perspective (Downing, 1996). Folks formulate and make purposeful un-rare sense of belonging through their linkages to localities and the artefacts they effectively utilize to delineate amplitude (Earle, 1997). These artefacts encompasses not only rewarding resources, but also communal ones, concrete proof of a faction sense of belonging. These may consist of accoutrements as interment terrains, locality and sectarian traditional sanctorum and spots just to mention a few. These may encompass fiscal frameworks that produces an indigenous sense of belonging, such as an intermittent marketplace among others (Koenig, 2001).

\section{Research Methodolgy}

\subsection{Preview}

The segment presents the research methodological processes underpinning the study. It touches on the research design, population, sampling and its associated techniques and the like.

\subsection{Research Approach}

In allusion to the assertion of Yates (2004), two pivotal approaches are indispensable as far as modern day research study is concerned. These are as follows: (a) qualitative (b) quantitative. According to Creswell (2009), qualitative approach encompasses the circumstantial outlook of how intelligence is produced whereas a quantitative research involves a series of actions geared towards the advancement of confirmable or possible trial panacea to an enigma and ideology which happens to be generalistic and spans across a considerable group of set-ups (Creswell, 2013).

Strictly speaking, both quantitative and qualitative types of approaches have their fortitudes and vulnerabilities. One of the glaring fortitudes of the quantitative type is the proportionate velocity with which study is embarked upon. Both qualitative (5-Point Likert Scale) and quantitative \{Relative Importance Index (RII), Descriptive statistics, Microsoft Excel, SPSS (version 22.0)\} approaches were employed for the study.

\subsection{Research Design}

Beck (2012) defined a research design as the investigator's absolute blueprint for eliciting response to the research objectives or questions just to mention a few. Descriptive research design was opted for as the frame of reference underpinning the study. Descriptive survey is a form of non-explorative inquisition in which the handling of changeables and haphazardness of samples are far-fetched (Leedy \& Ormrod, 2010). Within this research type, the researcher draws nearer to the paradox as it stands, thereby influencing the course in which deductions can be made in consonance with the study's instrumental findings. 


\subsection{Population Selection}

A research population can be defined as the summation of a carefully-delineated group of folks that have a generally known, confining attributes (Moore, 2009). The targeted population for this study was made up of 65 staff and inhabitants belonging to BPA and Gyama New Settlement Township respectively with some peculiar attributes in unison.

\subsection{Sampling Technique and Sample Size Determination}

Sampling encompasses the series of actions to pick out an apportionment affiliated to the population to typify the population in its entirety (Creswell, 2009). A sample on the other hand, comprises of answerable parts that make up the population (Polit \& Hungler, 1999) and mostly employed in colossal survey for monetary, vis-a-vis correctitude purposes (Creswell, 2009). The sampling technique adopted for the study based on its purpose, design, and practical implication of the research topic was purposive sampling. Purposive technique was adopted for the study because the investigator thought it wise to familiarize himself with what ought to be known and proceeded to unearth people who could and were willing to provide the information by virtue of knowledge or experience. A sample size of 89 employees which represented respondents sampled from employees belonging to BPA as well as resettlers of New Gyama Settlement locality (BPAGs) was used for the study. The determination of the sample size was based on Saunders, Lewis and Thornhill (2007) mathematical equation. In the strict sense, only 75 questionnaires returned to the researcher was used in the data analysis. The 75 questionnaires returned represented $84.3 \%$ rate of response and inadvertently used in the data analysis.

\subsection{Interviews and Data Management}

Interviews by questionnaire administration were carried out through field visits to the study area during which BPA employees and Gyama New Resettlement within the study area were selected purposively. Augmenting one's intelligence pertaining to a subject matter can be achieved in myriads of modes. Strategies included prudently appraising erstwhile literature just to mention a few. The methodology assumed for this study will also be scientific, conventional unbiased, systematic, methodology and rigorous. This ensured reliable and relevant data and the application of appropriate statistical techniques in the analysis of the data in order to control potential errors and arrive at accurate conclusions.

Both primary and secondary data sources were relied upon for the study. Primary data was obtained through questionnaire administration, interview guides, and observation. Secondary data was obtained from BPA, relevant publications, newspapers, institutional reports, journals, national level documents and the internet. The data collection techniques used were secondary data extraction and interviews. Secondary data extraction were obtained from BPA among others. The questionnaire sought to gather the following information; socio-demographics, closed and open-ended questions relating to resettlement schemes across the globe, with special emphasis on BPA and New Gyama Settlement precinct. The study was pilot tested to ensure efficacy of questionnaire administration methods, responsiveness on the part of the respondents were reasonable and problem free. Minor adjustments were made to ensure the accuracy and consistency of the questionnaire. Questionnaires were randomly sampled with occasional assistance in translation into local dialects to explain some aspects to respondents. The completed questionnaires were reviewed and randomly audited to ensure accuracy and precision.

\subsection{Data Analysis Method}

Tools employed for the analysis of data garnered in the study include: SPSS Version 22.0, Microsoft Excel, descriptive statistics among others. Thereafter, the findings were presented using graphs (pie charts and bar graphs) and tables among others. Furthermore, the study employed the Relative Importance Index (RII) method to identify the key attributes of effective resettlement plan, determine the distinctive social implications of resettlement schemes on displaced individuals caused by dam construction as well as investigate the critical socio-cultural issues associated with resettlement schemes in Ghana with special emphasis on BPA via the resettlers at Gyama New Settlement Township as the case study organization and locality. The 5-Point Likert Scale ranging from 1 (very irrelevant) to 5 (completely relevant) was applied and transformed to Relative Importance Indices (RII) for each of the factors represented as below:

$$
R I I=\sum_{1}^{5} \frac{a_{i} n_{i}}{5 N}
$$

Where: 
$\mathrm{a}=$ constant expressing the weight given to each factor by the respondents (ranging from 1 to 5 ).

$\mathrm{n}=$ frequency of each response

$5=$ a constant (i.e. 5 in this case), and

$\mathrm{N}=$ total number of respondents. The RII value had a range from 0 to 1 ( 0 not inclusive), the higher the value of RII, the more significant the key attributes of effective resettlement plan, distinctive social implications of resettlement schemes on displaced individuals caused by dam construction as well as the critical socio-cultural issues associated with resettlement schemes in Ghana. The RII was used to rank (R) the different key attributes of effective resettlement plan, distinctive social implications of resettlement schemes on displaced individuals caused by dam construction as well as the critical socio-cultural issues associated with resettlement schemes in Ghana as suggested by the respondents' at BPAGs. The ranking was used to compare the relative importance of the factors as perceived by the respondents. Each cause of RII perceived by all respondents was used to assess the general and overall rankings in order to give an overall pictorial view of the key attributes of effective resettlement plan, distinctive social implications of resettlement schemes on displaced individuals caused by dam construction as well as the critical socio-cultural issues associated with resettlement schemes in Ghana, vis-à-vis strategic initiatives that can be put in place to manage the afore-mentioned issues raised.

\subsection{Validity and Reliability}

Reliability of a test connotes the extent of how accurately the research apparatus quantifies a variable (Szafram, 2012). An apparatus is deemed reliable if it estimates the authentic scoring of the variable devoid of mistakes whereas validity is the extent to which a standard is estimating what it purports to measure (Creswell, 2013). Techniques were adopted to make certain that the data gathering apparatus factored into the study were reliable and valid. The first measure was to utilize diversified data garnering accoutrements for the study. The findings from these diverse data gathering tools were triangulated or compared to see whether they exemplified same findings.

\subsection{Ethical Consideration}

According to Cooper and Schindler (2008), ethics are the norms or standards that guide moral choices about our behavior and relationships with others. Potential respondents to the questionnaires were therefore given assurance that the data collected would be used for the stated purpose and in no way identified the provider of such data. Also, respondents were informed to be objective since the researcher was not looking for right or wrong answers.

\subsection{Brief Profile of Case Study Organization and Locality}

The next subsection touches on the brief profile encompassing the case study organization and locality.

\subsubsection{BPA Historical Perspective}

The development of a hydropower scheme on the Black Volta River at the Bui Gorge had been the subject of many studies; namely, detailed studies by J.S. Zhuk Hydroprojeckt of the USSR in 1966, a Feasibility Study by Snowy Mountains Eng. Corp (SMEC) of Australia in 1976 and another Feasibility Study by Coyne et Bellier of France in 1995.The proposed 400 MW Bui hydropower scheme was considered to be the most technically and economically attractive hydropower site in Ghana after the Akosombo and Kpong hydro power plants. The feasibility study of 1995 was subsequently updated by Coyne and Bellier in October 2006 to enable the commencement of the project (BPA Manual, 2015).

The Bui Power Authority Act, 2007 (Act 740) was enacted by the Parliament of Ghana and assented by the President in July 2007 to establish an Authority known as the Bui Power Authority (BPA) which was to plan, execute and manage the Bui Hydroelectric Project. The Bui Hydroelectric Project was designed primarily for hydropower generation. It however includes the development of an irrigation scheme for agricultural development and presents an opportunity for enhanced ecotourism and fisheries. It also includes a Resettlement and Community Support Program.

\subsubsection{Vision \& Mission Statement}

The following emphasis on the vision and mission statement that pertains to BPA.

\subsubsection{Vision Statement}

BPA will be a shining exhibit of the professional capability and competence of Ghanaian human resources and institutions.

\subsubsection{Mission Statement}


Develop, deploy and sustainably utilize the resources of the Black Volta to derive the optimum national benefits primarily by providing electricity at base price to spur industrial and agricultural production and impact the lives of millions.

Figure 1 is a diagrammatic representation of Ghana map showing dam site and resettlement activities at Bui Township.

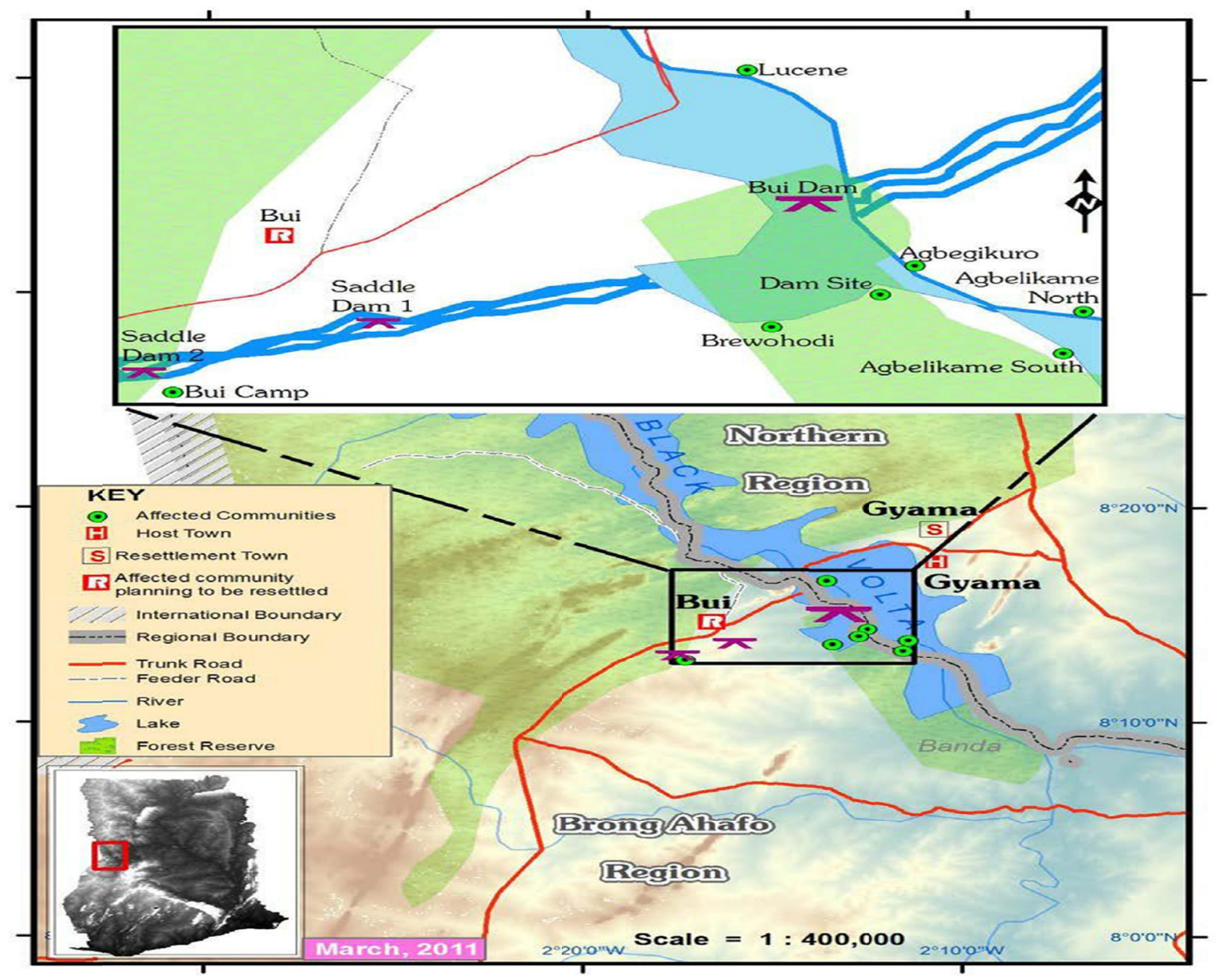

Figure 1. Map of Ghana showing dam site and resettlement activities

Source: Mettle (2011)

\section{Results and Discussion}

\subsection{Overview}

As cited earlier, the main objective of this study is to assess the resettlement scheme of the Bui hydro project using the social lens. To do this, the study collected data from employees belonging to BPA, in addition to selected resettlers of Gyama New Settlement Township (BPAGs) to answer the following research questions:

1) What are the key attributes of effective resettlement plan in Ghana?

2) What are the distinctive social implications of resettlement schemes on displaced individuals caused by dam construction in Ghana?

3) What are the critical socio-cultural issues associated with resettlement schemes in Ghana?

4) What strategic initiatives should be put in place to manage the critical socio-cultural issues associated with resettlement schemes in Ghana?

Collectively, this section presents the analysis of the data collected and discussed with respect to the literature review, description of statistical analysis in relation to the research questions posed in the study with appropriate tables and figures. This includes demographics of participants, in addition to the above cited research questions 
with a heavy reliance on BPAGs participants.

\subsection{Socio-Demographic Characteristics of Participants}

This section of the chapter deals with the demographic information of participants. It commences with the age distribution, marital status, service length, educational background, and key attributes of effective resettlement plan, distinctive social implications of resettlement schemes on displaced individuals caused by dam construction, in addition to the critical socio-cultural issues associated with resettlement schemes in Ghana. First and foremost, the study solicited for participants' gender (sex). The responses were then analyzed using frequency and percentage tables.

Table 3. deals with the gender of participants at BPAGs.

Table 3. Gender of participants

\begin{tabular}{lcc}
\hline Gender & Frequency & Percentage (\%) \\
\hline Male & 49 & 65.3 \\
Female & 26 & 34.7 \\
Total & $\mathbf{7 5}$ & $\mathbf{1 0 0 . 0}$ \\
\hline
\end{tabular}

Source: Author's Field Data (AFD), 2017

Table 3 above clearly shows that out of the 75 participants belonging to BPAGs, 49 representing $65.3 \%$ were males and 26 which represented $34.7 \%$ were females.

Table 4 presents the ages of participants at BPAGs.

Table 4. Ages of participants

\begin{tabular}{lccc}
\hline & Age Ranges & Frequency & Percentage (\%) \\
\hline $18-25$ & 17 & 26.7 \\
$26-35$ & 23 & 30.7 \\
$36-45$ & 29 & 38.7 \\
Above 45 & 6 & 3.9 \\
Total & $\mathbf{7 5}$ & $\mathbf{1 0 0 . 0}$ \\
\hline
\end{tabular}

Source: Author's Field Data, 2017

In allusion to table 4 above, $26.7 \%$ of the participants' were between the ages of 18-25 years with an accompanying frequency of $17,30.7 \%$ were between the ages of $26-35$ years and subsequently had a frequency of $23,38.7 \%$ of the participants' with a frequency of 29 fell into the age bracket of between $36-45$ years. However, those above the 45 years category recorded a percentage scoring of $3.9 \%$ with a frequency of 6 . It is so glaring that majority of the workforce and inhabitants belonging to BPAGs are in the youthful stages of their lives which will ultimately foster performance, efficiency as well as productivity to a significant extent.

Table 5 depicts the marital status of participants' at BPAGs.

Table 5. Marital status of participants

\begin{tabular}{lcc}
\hline Marital Status & Frequency & Percentage (\%) \\
\hline Single & 23 & 30.7 \\
Married & 41 & 54.7 \\
Separated & 7 & 9.3 \\
Divorced & 4 & 5.3 \\
Total & $\mathbf{7 5}$ & $\mathbf{1 0 0 . 0}$ \\
\hline
\end{tabular}

Source: Author's Field Data, 2017 
With reference to table 5 cited above, it can be deduced that the majority of the participants are married couples with the highest percentage mark of $54.7 \%$ and a frequency of 41 . This was closely followed by the single category with an occurrence number of 23 via percentage score of $30.7 \%$. However, 4 out of the participants had a percentage mark of $5.3 \%$, representing the divorced category whereas those belonging to the separation option recorded a percentage score of $9.3 \%$ with an accompanying frequency of 7 . Marriage is a state of being responsible in life. The marital status which epitomizes the high rate of occurrence of married people at BPAGs will invariably influence the responsibility levels of workers and resettlers in contention as regards their day-to-day work executions/job specifications, enhanced maturity levels as regards eliciting precise responses to the questions contained in the questionnaire just to mention a few.

Table 6 shows the length of service/stay of participants' at BPAGs.

Table 6. Service/stay length of participants

\begin{tabular}{lcc}
\hline Length of Service/Stay (Years) & Frequency & Percentage (\%) \\
\hline $1-5$ & 41 & 54.7 \\
$6-10$ & 34 & 45.3 \\
$11-15$ & - & 0.0 \\
Exceeding 16 & - & 0.0 \\
Total & $\mathbf{7 5}$ & $\mathbf{1 0 0 . 0}$ \\
\hline
\end{tabular}

Source: Author's Field Data, 2017

As ascribe to the above cited table 6, it can be deduced from the participants that those in the 1-5 year range had the maximum number of occurrence and a percentage scoring (PS) of 41 and $54.7 \%$ respectively. It was closely accompanied by the employees/resettlers who took part in the survey and had in diversed ways been domiciled in the locality and rendered their service to the above-mentioned corporate entity spanning between 6 to 10 years had frequency of 34 and subsequently attracted a percentage scoring of $45.3 \%$. It is worth noting that employees/resettlers who have been working/living within the jurisdiction BPAGs for more than a decade and a half, i.e. to say, those that fell within the year range of between 11 and 15 via those exceeding 16 years interestingly recorded no frequency and percentage scoring during the study $(0$ and $0.0 \%)$ respectively.

Table 7 illuminates on the educational background of participants' at BPAGs.

Table 7. Educational background of participants

\begin{tabular}{lcc}
\hline Highest Form of Qualification & Frequency & Percentage (\%) \\
\hline SSCE/WASSCE & 4 & 5.3 \\
HND & 18 & 24.0 \\
First Degree & 32 & 42.7 \\
Second Degree & 13 & 17.3 \\
Other Professionals & 8 & 10.7 \\
Total & $\mathbf{7 5}$ & $\mathbf{1 0 0 . 0}$ \\
\hline
\end{tabular}

Source: Author's Field Data, 2017

The table above (7) depicts that $24.0 \%$ of the participants were holders of HND qualification and had a maximum frequency of $18,42.7 \%$ were first (bachelors) degree holders who had a frequency of $32.17 .3 \%$ represented second degree (masters) holders with an accompanying occurrence number of 13 whereas those with a percentage scoring of $10.7 \%$ in addition to a frequency of 8 , represented various professional qualification holders as at the time of data collection. SSCE/WASSCE category also recorded a frequency rate and percentage scoring of 4 and $5.3 \%$ respectively. Data collection on the socio-demographic characteristics of BPAGs' participants' maintains a relatively youthful workforce with myriads of diverse educational qualifications. A higher percentage of the workers have at least an HND background. The study also revealed that the males are 
the predominant gender and majority of the participants belonging to BPAGs. From the results gathered throughout this study, it is so glaring that a high threshold of the employees fall between the ages of 18 to $45 y e a r s$ with an accompanying frequency and percentage scoring of 69 and $92.0 \%$. Coincidentally, this age bracket happens to be the most popular range at which most people in this part of the world get married and start living responsibly.

Table 8 presents the views of participants' on key attributes of effective resettlement plan (ERP) at BPAGs, mean, RII values and its subsequent rankings.

Table 8. Participants' view on key attributes of effective resettlement plan, mean, RII \& Ranking

\begin{tabular}{|c|c|c|c|}
\hline Key Attributes of Effective Resettlement Plan & Mean Values & RII Scoring & Ranking \\
\hline $\begin{array}{l}\text { Sustainable and effective compensation framework } \\
\text { (SECF) }\end{array}$ & 4.39 & 0.878 & $1^{\text {st }}$ \\
\hline Effective participation of APs (EPAP) & 4.18 & 0.832 & $2^{\text {nd }}$ \\
\hline $\begin{array}{l}\text { Thorough description of resettlement assistance and } \\
\text { restoration of livelihood activities (TDLA) }\end{array}$ & 3.93 & 0.787 & $3^{\text {rd }}$ \\
\hline $\begin{array}{l}\text { Consideration of short and long term income strategies, } \\
\text { government responsibility of AP's right (CSLS) }\end{array}$ & 3.85 & 0.770 & $4^{\text {th }}$ \\
\hline Strict adherence to monitoring and evaluation regimes & 3.08 & 0.615 & $5^{\text {th }}$ \\
\hline $\begin{array}{l}\text { Clarity of definition in terms of entitlements, eligibility, } \\
\text { ethnicity, cultural and political attributes of APs (CDEP) }\end{array}$ & 2.80 & 0.561 & $6^{\text {th }}$ \\
\hline
\end{tabular}

Source: Author's Field Data, 2017

The table 8 above and figure 2 below indicates that participants at BPAGs opted "Sustainable and effective compensation framework (SECF)" as the $1^{\text {st }}$ most pivotal as far as key attributes of effective resettlement plans in Ghana is concerned. "SECF" construct recorded an RII value of 0.878 based on the 5-Point Likert scale's order of relevance via a mean score of 4.39 as compared to the remaining 5 constructs. The determinant in contention captioned "SECF" was closely accompanied by "Effective participation of APs (EPAP)", "Thorough description of resettlement assistance and restoration of livelihood activities (TDLA)", "Consideration of short and long term income strategies, government responsibility of AP's right (CSLS)" categories with accompanying RII and mean scorings of $0.832\left(2^{\text {nd }}\right), 0.787\left(3^{\text {rd }}\right)$ as well as $0.770\left(4^{\text {th }}\right)$ via $4.18,3.93$ and 3.85 respectively. To add to this, "Strict adherence to monitoring and evaluation regimes (SAME)", in addition to "Clarity of definition in terms of entitlements, eligibility, ethnicity, culture and political attributes of APs (CDEP) parameters had respective RII values of 0.615 and 0.561 via mean scores of 3.08 and 2.80 and invariably ranked $5^{\text {th }}$ and $6^{\text {th }}$ accordingly.

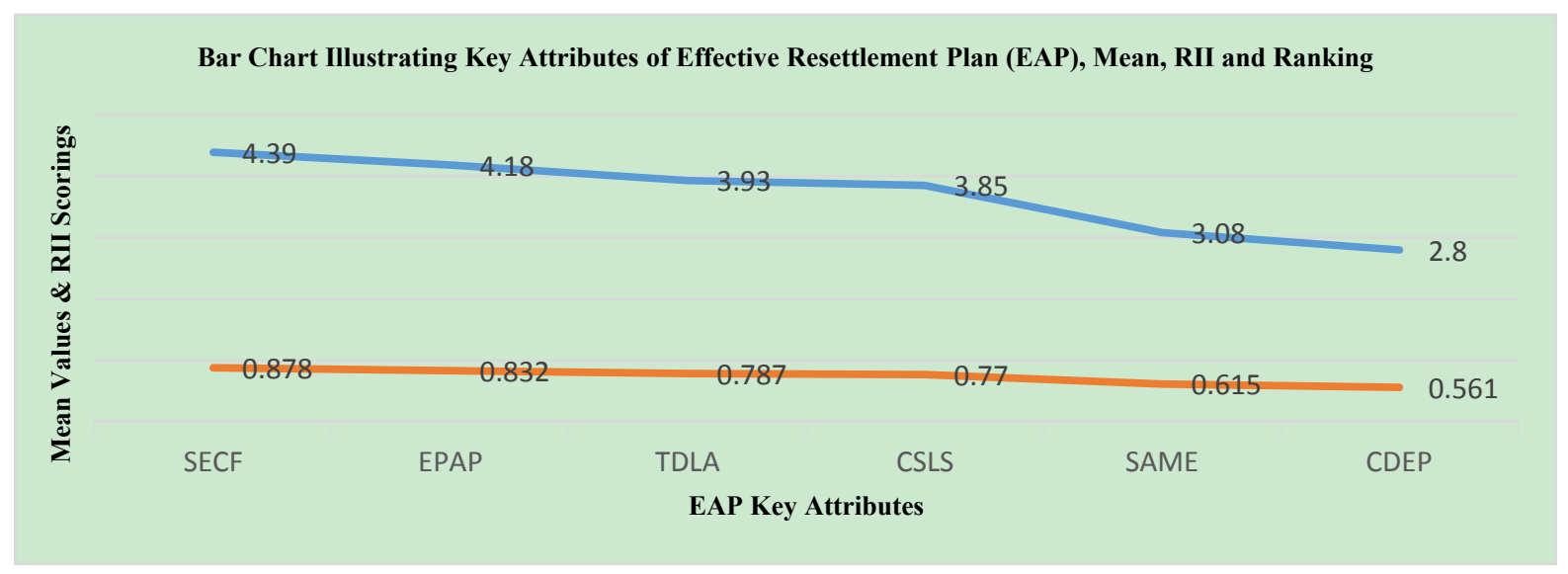

Figure 2. Effective resettlement plan attributes

Source: AFD (2017) 
Table 9 presents the views of participants' on distinctive social implications of resettlement schemes (DSIRSs) on displaced individuals (DIs) caused by dam construction at BPAGs, mean, RII values and its subsequent rankings.

Table 9. Participants' view on distinctive social implications of resettlement schemes (DSIRSs) on displaced individuals (DIs) caused by dam construction, mean, RII \& Ranking

\begin{tabular}{|c|c|c|c|}
\hline $\begin{array}{l}\text { Distinctive Social Implications of Resettlement } \\
\text { Schemes on Displaced Individuals Caused by Dam } \\
\text { Construction }\end{array}$ & Mean Values & RII Scoring & Ranking \\
\hline $\begin{array}{l}\text { Loss of asset that support community livelihoods } \\
\text { (LOAL) }\end{array}$ & 4.56 & 0.912 & $1^{\mathrm{st}}$ \\
\hline Economic upheavals (ECUV) & 4.33 & 0.867 & $2^{\text {nd }}$ \\
\hline $\begin{array}{l}\text { Adverse health implications for some nearby } \\
\text { communities (AHIC) }\end{array}$ & 3.97 & 0.795 & $3^{\text {rd }}$ \\
\hline Loss of cultural identity (LOID) & 3.56 & 0.713 & $4^{\text {th }}$ \\
\hline $\begin{array}{l}\text { Adverse impact of conservation efforts such as ancestral } \\
\text { heritage sites (AIHS) }\end{array}$ & 3.32 & 0.664 & $5^{\text {th }}$ \\
\hline Shift in social roles (SISR) & 2.84 & 0.568 & $6^{\text {th }}$ \\
\hline
\end{tabular}

Source: Author's Field Data, 2017

With reference to table 9 above and figure 3, it can be inferred that BPAGs" participant selected "Loss of asset that support community livelihoods (LOAL)" as the most influencing as ascribe to the distinctive social implications of resettlement schemes on displaced individuals caused by dam construction in Ghana. The determinant under scrutiny (LOAL) had an optimum mean score of 4.56, in addition to an RII value of 0.912 as revealed by the 5-Point Likert model's order of significance. It was edgily accompanied by "Economic upheavals (ECUV)", "Adverse health implications for some nearby communities (AHIC)", "Loss of cultural identity (LOID)", "Adverse impact of conservation efforts such as ancestral heritage sites (AIHS)" and lastly "Shift in social roles (SISR) determinants. To add to this, the above-mentioned 5 constructs had mean values of $4.33,3.97,3.56,3.32$ and 2.84 , in addition to RII scorings of $0.867,0.795,0.713,0.664$ and 0.568 and were inadvertently rated $2^{\text {nd }}, 3^{\text {rd }}, 4^{\text {th }}, 5^{\text {th }}$ and $6^{\text {th }}$ respectively.

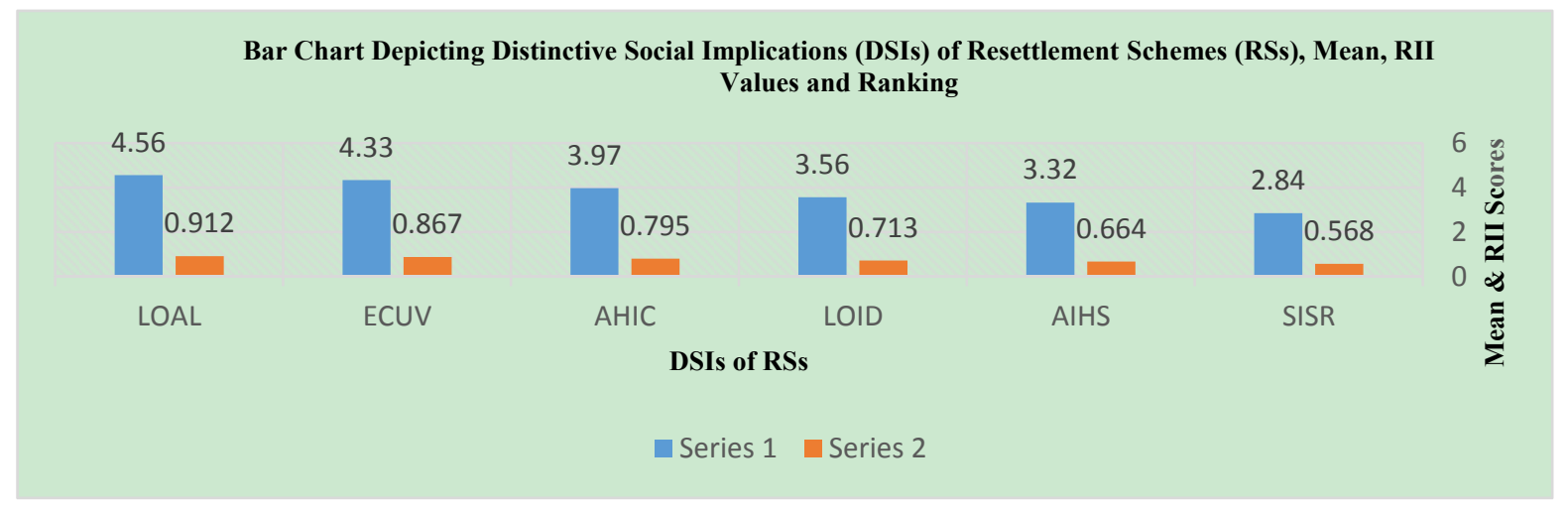

Figure 3. Distinctive social implications of RSs

Source: AFD, (2017)

Table 10 presents the views of participants' on critical socio-cultural issues associated with resettlement schemes at BPAGs, mean, RII values and its subsequent rankings. 
Table 10. Participants' view on critical socio-cultural issues associated with resettlement schemes, mean, RII \& Ranking

\begin{tabular}{lccc}
\hline $\begin{array}{l}\text { Critical Socio-Cultural Issues Associated with } \\
\text { Resettlement Schemes }\end{array}$ & Mean Values & RII Scoring & Ranking \\
\hline Social or psychological marginality (SOMG) & 4.31 & 0.867 & $1^{\text {st }}$ \\
Social disarticulation/social costs (SDSC) & 3.93 & 0.786 & $2^{\text {nd }}$ \\
$\begin{array}{l}\text { Depreciation of ethnic group's social status (DTSS) } \\
\text { Dispersion and fragmentation of existing }\end{array}$ & 3.67 & 0.733 & $3^{\text {rd }}$ \\
communities (DIEX) & & 0.629 & $4^{\text {th }}$ \\
Educational loss as a distinctive and additional risk & 2.87 & 0.573 & $5^{\text {th }}$ \\
(ELAR) & & & $6^{\text {th }}$ \\
Loss of control over physical space of APs (LVAP) & 2.13 & 0.426 & \\
\hline
\end{tabular}
Source: Author's Field Data, 2017

As per the critical socio-cultural issues associated with resettlement schemes in Ghana, participants at BPAGs chose "Social or psychological marginality (SOMG)" parameter as the most detrimental that cannot be underestimated in that recorded an RII scoring of 0.867 as well as a mean score of 4.31 . The computed RII value of "SOMG" was based on the 5-Point Likert scale's order of importance which was later transformed into the Relative Importance Index (RII) (see table 10 above and figure 4 below). Furthermore, "SOMG" as the acronym suggest was closely followed by "Social disarticulation/social costs (SDSC)", "Depreciation of ethnic group's social status (DTSS)", in addition to "Dispersion and fragmentation of existing communities (DIEX)" categories. These afore-mentioned determinant had RII scorings of $0.786,0.733$ via 0.629 and were subsequently ranked $2^{\text {nd }}$, $3^{\text {rd }}$ and $4^{\text {th }}$, in addition to mean scorings of $3.93,3.67$, and 3.14 respectively. However, both "Education as a distinctive and additional risk, designated as "ELAR" for the purposes of this study, as well as "Loss of control over physical space of APs (LVAP) constructs had respective RII scorings of 0.573 and 0.426 and a concomitant mean scores of $2.87\left(5^{\text {th }}\right)$ and $2.13\left(6^{\text {th }}\right)$ accordingly.

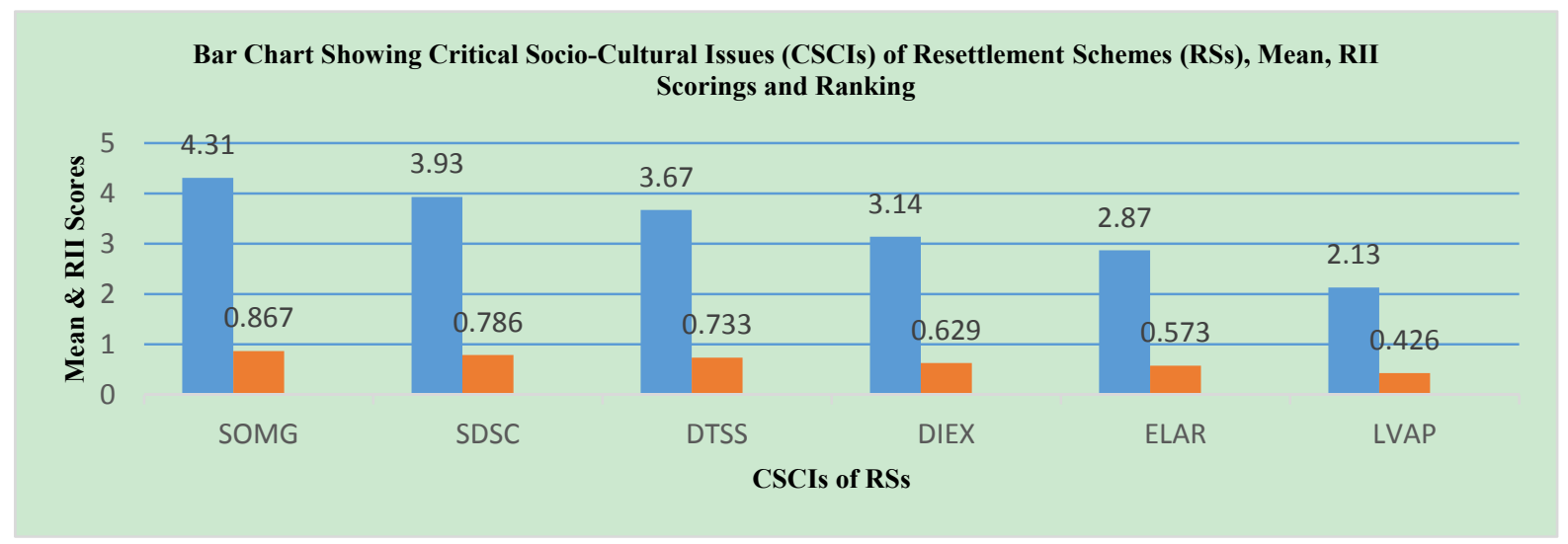

Figure 4. Critical socio-cultural factors of RSs

Source: AFD, (2017)

\subsection{Detailed Discussion of Results}

The 75 participants' suggestions as depicted on the questionnaires conscentized the researcher to assign weighted values to each of the parameters identified as the key attributes of effective resettlement plans, distinctive social implications of resettlement schemes on displaced individuals caused by dam construction in Ghana. Furthermore, the critical socio-cultural issues associated with resettlement schemes in Ghana, which when given the requisite precedence will undoubtedly culminate into its superior quality functioning, vis-à-vis living up to its billing of success as well as the attainment of desired project outcomes in the long run.

Candidly speaking, with reference to the key attributes of effective resettlement plans in Ghana, 6 essential 
categories were opined by the participants. These are (1) Sustainable and effective compensation framework (SECF) (RII=0.878) (4.39); (2) Effective participation of APs (EPAP) (RII=0.832) (4.18); (3) Thorough description of resettlement assistance and restoration of livelihood activities (TDLA) (RII=0.787) (3.93); (4) Consideration of short and long term strategies/government responsibility of APs' rights (CSLS) (RII=0.770) (3.85); (5) Strict adherence to monitoring and evaluation regimes (SAME) (RII=0.615) (3.08); in addition to (6) Clarity of definition in terms of entitlements, eligibility, ethnicity, etc. (CDEP) (RII=0.561) (2.80).

Secondly, 6 distinctive social implications of resettlement schemes on displaced individuals caused by dam construction were ranked based on the order of relevance on the Five Point Likert scale which was later upgraded into the Relative Importance Index (RII) in consonance with the mean values of the parameters factored into the study. According to the ranking relating to the RII, 6 constructs were realized by the participants namely: (1) Loss of asset that supports community Livelihoods (LOAL) (RII=0.912) (4.56); (2) Economic upheavals (ECUV) (RII=0.867) (4.33); (3) Adverse health implications for communities (AHIC) (RII=0.795) (3.97); (4) Loss of cultural identity (LOID) (RII=0.713) (3.56); (5) Adverse impact of conservation efforts (ancestral heritage sites) (AIHS) (RII=0.664) (3.32); vis-à-vis (6) Shift in social roles (SISR) (RII=0.568) (2.84).

Lastly, with respect to the critical socio-cultural issues associated with resettlement schemes in Ghana, the participants intimated 6 critical determinants as (1) Social or psychological marginality (SOMG) (RII=0.867) (4.31); (2) Social disarticulation/social costs (SDCC) (RII=0.786) (3.93); (3) Depreciation of ethnic group's social status (DTSS) (RII=0.733) (3.67); (4) Dispersion and fragmentation of existing communities (DIEX) (RII=0.629) (3.14); (5) Education loss as a distinctive and additional risk (ELAR) (RII=0.573) (2.87); as well as (6) Loss of control over physical space of APs (LVAP) (RII=0.426) (2.13).

\subsection{Detailed Discussion of Results Pertaining to Research Question 1}

This subsection presents a detailed discussion of results relating to research question 1:

\subsubsection{Sustainable and Effective Compensation Framework}

With respect to the key attributes of effective resettlement plan in Ghana, participants at BPAGs selected "Sustainable and effective compensation framework (SECF) as the most influential that cannot be overemphasized. "SECF" construct had an RII scoring of 0.878 and was ranked $1^{\text {st }}$, based on the 5-Point Likert scale's relevance order, in addition to an optimum mean value of 4.39 (see table 8 and figure 2 cited earlier). Interestingly, the participants' fact findings agrees with the works of Arthur (2016), Sutcliffe (2009), in addition to what was intimated by ADB (2010).

\subsubsection{Effective Participation of APs}

"Effective participation of APs (EPAP)" was ranked $2^{\text {nd }}$ by the participants at BPAGs, in consonance with the key attributes of effective resettlement plans in Ghana. The construct captioned "EPAP" recorded an RII scoring of 0.832 as revealed by the 5 -Point Likert scale's order of significance, in addition to its mean value of 4.18 (refer to table 8 and figure 2 afore-cited). Candidly, the extensive research projects executed by Mettle (2011), Kyei-Dompreh (2012), Cernea (2000) as well as publication of ADB (2010) tallies with the participants' discovery during the study.

\subsubsection{Thorough Description of Resettlement Assistance and Restoration of Livelihood Activities}

As per the key attributes of effective resettlement plan in Ghana, participants at BPAGs intimated "Thorough description of resettlement assistance and restoration of livelihood activities (TDLA)" as the $3^{\text {rd }}$ most crucial comparatively. "TDLA" determinant recorded an RII score of 0.787 in association with the 5-Point Likert model's pecking order, and invariably had a mean score of 3.93 (see table 8 and figure 2 afore-cited). It is worth noting that the participants' revelations coheres with the works of De Wet (2006), Tetteh (2012), and Arthur (2016) as well as what was publicized by ADB (2010) and WCD (2000a).

\subsubsection{Consideration of Short and Long Term Strategies/Government Responsibility of APs' Rights}

Pertaining to the key attributes of effective resettlement plans in Ghana, participants at BPAGs opted for "Consideration of short and long term strategies/government responsibility of AP's rights (CSLS) as the $4^{\text {th }}$ most pivotal. "CSLS" had an RII scoring of 0.770 in tandem with the 5-Point Likert scale's order of importance, via its mean value of 3.85 (refer to table 8 and figure 2 cited earlier). Put simply, the participants' findings synchronizes with the submissions of Cernea (2000), ADB (2010) as well as what was reported by Miine (2014) and De Wet (2006).

\subsubsection{Strict Adherence to Monitoring and Evaluation Regimes}

The construct "Strict adherence to monitoring and evaluation regimes (SAME)" was rated $5^{\text {th }}$ by BPAGs' 
participants with respect to the key attributes of effective resettlement plans in Ghana. "SAME" recorded an RII scoring of 0.615 as revealed by the 5-Point Likert scale's order of significance which was later upgraded into the Relative Importance (RII), including a mean score of 3.08 (refer to table 8 and figure 2 afore-cited). Strictly speaking, the participants' findings conform to the assertions of UNHCR (2004) as well as ADB (2010), not losing sight of the postulates of De Wet (2006) and Sutcliffe (2009).

4.4.6 Clarity of Definition in Terms of Entitlements, Eligibility, Ethnicity, etc.

More so, in accordance with the key attributes of effective resettlement plans in Ghana, participants chose "Clarity of definition in terms of entitlements, eligibility, etc." designated as "CDEP" as the $6^{\text {th }}$ most instrumental that cannot be overemphasized. This perspective recorded an RII scoring of 0.561 in consonance with the 5-Point Likert model's relevance order and subsequently had a mean score of 2.80 as compared to the other 5 constructs mentioned earlier (refer to table 8 and figure 2 cited earlier). It is interesting to note that the comprehensive research project embarked upon by Cernea (2000), in addition to publication ADB (2000) shares direct semblance with the participants' revelation during the study.

\subsection{Detailed Discussion of Results Relating to Research Question 2}

The following underpins the detailed discussion of results that pertains to research question 2:

\subsubsection{Loss of Asset That Supports Community Livelihoods}

Relating to the distinctive social implications of resettlement schemes on displaced individuals caused by dam construction in Ghana, participants' at BPAGs opted for "Loss of asset that supports community livelihoods (LOAL)" as the front runner $\left(1^{\text {st }}\right)$ comparatively. Simply put, "LOAL" recorded an RII scoring of 0.912 based on the 5-Point Likert scale's order of importance and inadvertently had a mean score of 4.56 (see table 9 and figure 3 cited earlier). It is worth noting that the participants' findings appears to be at congruence with the postulates of Egre (2007) and Bennett and McDowell (2012), captured in their respective publication entitled "Displaced: The Human Cost of Development and Displacement", in addition to "Revised Final Report on Benefit Sharing Issues: Compendium on Relevant Practices".

\subsubsection{Economic Upheavals}

"Economic upheavals (ECUV)" was chosen as the $2^{\text {nd }}$ most instrumental determinant, with respect to the distinctive social implications of resettlement schemes on displaced individuals caused by dam construction in Ghana. The construct (ECUV) had an RII scoring of 0.867 as revealed by the 5-Point Likert scale's pecking order and invariably recorded a mean value of 4.33 (see table 9 and figure 3 afore-cited). In the strict sense, the participant revelation agrees with the works of Fratkin (2014), Biswas (2013), as well as Arthur (2016).

\subsubsection{Adverse Health Implications for Communities}

As per the distinctive social implications of resettlement schemes on displaced individuals caused by dam construction in Ghana, BPAGs' participants intimated "Adverse health implications for some nearby communities (AHIC)" as the $3^{\text {rd }}$ most essential based on its computed RII value (0.795), in addition to its mean score (3.97). This was in agreeable to the 5-Point Likert scale's relevance order as well as the results spelt out in table 9 and what figure 3 depicts. Honestly, the submission of Kalitsi (2004) and Dzodzi (2006) will go unnoticed in this perspective as it directly agrees with the participants' fact findings during the study.

\subsubsection{Loss of Cultural Identity}

"Loss of cultural identity (LOID)" was rated $4^{\text {th }}$ by the participants at BPAGS, in consonance with the distinctive social implications of resettlement schemes on displaced individuals caused by dam construction in Ghana. "LOID" as the acronym elucidates recorded an RII value of 0.713 based on the 5-Point Likert scale's order of significance in tandem with its mean value of 3.56 (see table 9 and figure 3 afore-cited). It is worthy of note that the participant's discovery tallies with sustainable development affiliates like Peter (2013), Ferraro et al. (2011) in addition to the submission of Arthur (2016).

\subsubsection{Adverse Impact of Conservation Efforts (Ancestral Heritage Sites)}

As regards the distinctive social implications of resettlement schemes on displaced individuals caused by dam construction in Ghana, participants at BPAGs selected "Adverse impact of conservation efforts such as ancestral heritage sites (AIHS) as the $5^{\text {th }}$ most crucial comparatively. "AIHS" recorded an RII value of 0.664 as revealed by the 5-Point Likert scale's relevance order, in consonance with its mean score of (3.32) (refer to table 9 and figure 3 cited earlier). Put simply, the extensive research projects executed by the likes of Lerer and Scudder (2005) and Ansar et al. (2014), in addition to publications of ERM (2007), conforms to the participants' fact findings during the study. 


\subsubsection{Shift in Social Roles}

With particular reference to the distinctive social implications of resettlement schemes on displaced individuals caused by dam construction in Ghana, participants at BPAGs opted for "Shift in social roles (SISR)" as the $6^{\text {th }}$ most pivotal determinant that cannot be overemphasized. "SISR" construct recorded an RII scoring of 0.568 based on the 5-Point Likert scale's order of importance, which was later transformed into the Relative Importance Index (RII) (refer to table 9 and figure 3 afore-cited). Frankly, the participants' findings is consistent with the submissions of Cave et al. (2010), Andam et al. (2010, Ferraro et al. (2011), in addition to UNDP (2011a) report on dam construction and resettlement scheme issues across the globe.

\subsection{Detailed Discussion of Results in Allusion to Research Question 3}

The under-listed parameters accentuates on the detailed discussion of results as ascribe to research question 3 :

\subsubsection{Social or Psychological Marginality}

With reference to the critical socio-cultural issues associated with resettlement schemes in Ghana, participants' at BPAGs chose "Social or psychological marginality (SOMG)" as the most crippling determinant that ought to be accorded the requisite attention it deserves. "SOMG" parameter recorded an RII scoring of 0.867 based on the 5-Point Likert scale's order of significance, in allusion to its mean score of 4.31 (refer to table 10 and figure 4 cited earlier). Synonymously, the participants' findings appears to be in conformity with the postulates of Cernea (2000), Kyei-Dompreh (2012) as well as De Wet (2006).

\subsubsection{Social Disarticulation/Social Costs}

As per the critical socio-cultural issues associated with resettlement schemes in Ghana, participants' at BPAGs preferred option for the $2^{\text {nd }}$ most debilitating determinant was "Social disarticulation/social costs (SDSC) judging from its RII scoring (0.786). This was based on the 5-Point Likert scale's relevance order and inadvertently had a mean value of 3.93 (refer to table 10 and figure 4 afore-cited). Put simply, the participants' discovery agrees with the submissions of Kyei-Dompreh (2012), Downing (1996) as well as Koenig (2001).

\subsubsection{Depreciation of Ethnic Group's Social Status}

"Depreciation of ethnic group's social status" designated as "DTSS" was ranked $3^{\text {rd }}$ by the participants at BPAGs with respect to the critical socio-cultural issues associated with resettlement schemes in Ghana. That is to say, "DTSS" variable had an RII scoring of 0.733 as revealed by the 5-Point Likert scale's relevance order (quantitative), which was somewhere along the line upgraded into the Relative Importance (RII) (qualitative) and also had an mean score of 3.67 (see table 10 and figure 4 earlier cited). Interestingly, the participants' revelation is consistent with what was opined by the likes of Raschid et al. (2008), Koenig (2001), and Mettle (2011), De Wet (2006), in addition to the postulates of Tetteh (2012).

\subsubsection{Dispersion and Fragmentation of Existing Communities}

In connection with the critical socio-cultural issues associated with resettlement schemes in Ghana, participants' at BPAGs opted for "Dispersion and fragmentation of existing communities (DIEX) variable as the $4^{\text {th }}$ most devastating comparatively. "DIEX" construct had an RII value of 0.629 based on the 5-Point Likert model's pecking order, in tandem with the results displayed on table 10 and what figure 4 illustrates. Unquestionably, both Koenig (2001) and Downing (1996) research projects captioned "Toward Local Development and Mitigating Impoverishment in Development-Induced Displacement and Resettlement" as well as "Mitigating Social Impoverishment When People Are Involuntarily Displaced" is consistent with the participants' findings during the study.

\subsubsection{Education Loss as a Distinctive and Additional Risk}

"Education loss as distinctive and additional risk (ELAR)" was rated $5^{\text {th }}$ by the participants at BPAGs, in relation to the critical socio-cultural issues associated with resettlement schemes in Ghana. "ELAR" determinant recorded an RII scoring of 0.573 in association with the 5-Point Likert model's order of importance and inadvertently had a mean score of 2.87 (see table 10 and figure 4 cited earlier). It is revealing to be mindful of the fact that the participants' fact findings conforms to the assertions of Mahapatra (1999a), in addition to Koenig (2001).

\subsubsection{Loss of Control over Physical Space of APs}

Lastly, as ascribed to the critical socio-cultural issues associated with resettlement schemes in Ghana, participants' at BPAGs selected "Loss of control over physical space of APs" captioned as "LVAP" for the study in contention purposes, as the $6^{\text {th }}$ most devastating. "LVAP" category recorded a woeful RII scoring of 0.426 , 
based on the 5-Point Likert scale's order of importance and subsequently had a mean value of 2.13 (refer to table 10 and figure 4 afore-cited). It is worth noting that the participants' revelation agrees with the postulates of Oliver-Smith (1996), in addition to the submission of Arthur (2016) in his PhD Thesis captioned "Living with the Bui Dam: Implications for Community Livelihoods" accordingly.

\subsection{Achievement of Objectives}

The research objectives have been duly achieved in the preceding chapters. The first objective which reads "To identify the key attributes of effective resettlement plan in Ghana" has been vividly given the requisite precedence. Simply put, 6 notable parameters as regards the key attributes of effective resettlement plans were unearthed by the participants' at BPAGs. It has thus been captured by table 8 and figure 2 cited earlier. The second objective dubbed "To determine the distinctive social implications of resettlement schemes on displaced individuals caused by dam construction in Ghana" has also been addressed. This was attained through the distribution of questionnaires to 75 participants belonging to BPAGs. More so, 6 distinctive social implications of resettlement schemes on displaced individuals caused by dam construction in Ghana were realized by the researchers' based on the respondents' preferred options as it relates to the Relative Importance Index (RII) order of significance on the Five Point Likert scale and mean scores of the variables relevant to the study (see table 9 and figure 3 spelt out earlier). Lastly, the third objective entitled "To investigate the critical socio-cultural issues associated with resettlement schemes in Ghana" has also been tentatively dealt with. Simply put, 6 variables were suggested by the participants in tandem with the results spelt out in table 10 and what figure 4 depicts.

\section{Summary, Conclusions and Recommendations}

\subsection{Preview}

The chapter offers a summary of the entire study. Based on the summary, a general conclusion has been drawn and recommendations suggested for policy implications.

\subsection{Summary}

Strictly speaking, in connection with the key attributes of effective resettlement plans in Ghana, 6 variables were intimated by the participants based on the Five Point Likert Model relevance order which was later transformed in to the Relative Importance Index and mean values depicted in table 8 and figure 2 mentioned earlier, specifically: "Sustainable and effective compensation framework (SECF) (RII=0.878) (4.39)", "Effective participation of APs (EPAP) (RII=0.832) (4.18)", "Thorough description of resettlement assistance and restoration of livelihood activities (TDLA) (RII=0.787) (3.93)", "Consideration of short and long term strategies/government responsibility of APs' rights (CSLS) $(\mathrm{RII}=0.770)(3.85)$ ", "Strict adherence to monitoring and evaluation regimes (SAME) $(\mathrm{RII}=0.615)(3.08)$ ", in addition to "Clarity of definition in terms of entitlements, eligibility, ethnicity, etc. (CDEP) (RII=0.561) (2.80).

To add to this, as regards the distinctive social implications of resettlement schemes on displaced individuals caused by dam construction in Ghana, 6 pivotal constructs were suggested by the participants at BPAGs, namely: "Loss of asset that supports community Livelihoods (LOAL) (RII=0.912) (4.56)", "Economic upheavals (ECUV) (RII=0.867) (4.33)", "Adverse health implications for communities (AHIC) (RII=0.795) (3.97)", "Loss of cultural identity (LOID) (RII=0.713) (3.56)", "Adverse impact of conservation efforts (ancestral heritage sites) (AIHS) (RII=0.664) (3.32)", vis-à-vis "Shift in social roles (SISR) (RII=0.568) (2.84)".

Lastly, in allusion to critical socio-cultural issues associated with resettlement schemes in Ghana, again, 6 notable variables came to the fore. These are: "Social or psychological marginality (SOMG) $(\mathrm{RII}=0.867)(4.31)$ ", "Social disarticulation/social costs (SDCC) $(\mathrm{RII}=0.786)(3.93)$ ", "Depreciation of ethnic group's social status (DTSS) (RII=0.733) (3.67)", "Dispersion and fragmentation of existing communities (DIEX) (RII=0.629) (3.14), "Education loss as a distinctive and additional risk (ELAR) $(\mathrm{RII}=0.573)(2.87)$ " as well as "Loss of control over physical space of APs (LVAP) (RII=0.426) (2.13)".

\subsection{Conclusion}

Pertaining the dying emblems of the study, it is can be inferred that all the 75 participants belonging to BPAGs intimated the under-listed variables as the most crucial that cannot be underestimated as far as the key attributes of effective resettlement plan in Ghana is concerned: "Sustainable and effective compensation framework (SECF) $(\mathrm{RII}=0.878)$ (4.39)", "Effective participation of APs (EPAP) (RII=0.832) (4.18)", "Thorough description of resettlement assistance and restoration of livelihood activities (TDLA) (RII=0.787) (3.93)", "Consideration of short and long term strategies/government responsibility of APs' rights (CSLS) (RII=0.770) (3.85)", "Strict adherence to monitoring and evaluation regimes (SAME) (RII=0.615) (3.08)", in addition to "Clarity of definition in terms of entitlements, eligibility, ethnicity, etc. (CDEP) $(\mathrm{RII}=0.561)(2.80)$. 
Moreover, with respect to the distinctive social implications of resettlement schemes on displaced individuals caused by dam construction in Ghana, 6 phenomenal constructs identified were as follows: "Loss of asset that supports community Livelihoods (LOAL) $(\mathrm{RII}=0.912)(4.56)$ ", "Economic upheavals (ECUV) (RII=0.867) (4.33)", "Adverse health implications for communities (AHIC) (RII=0.795) (3.97)", "Loss of cultural identity (LOID) (RII=0.713) (3.56)", "Adverse impact of conservation efforts (ancestral heritage sites) (AIHS) $(\mathrm{RII}=0.664)$ (3.32)", vis-à-vis "Shift in social roles (SISR) (RII=0.568) (2.84)".

Furthermore, in connection with the critical socio-cultural issues associated with resettlement schemes in Ghana, participants' preferred option for the $1^{\text {st }}$ most pivotal construct was "social or psychological marginality" since it recorded the optimum RII and mean score of 0.867 and 4.31 respectively. To add to this, the 5 other constructs, namely: "social disarticulation/social costs", "depreciation of ethnic group's social status", "dispersion and fragmentation of existing communities", "education loss as a distinctive and additional risk", including "loss of control over physical space of APs" had accompanying RII and mean scores of "(0.786) (3.93)", "(0.733) (3.67)", “(0.629) (3.14)”, “(0.573) (2.87) as well as "(0.426) (2.13) respectively.

To all intents and purposes, prudently assessing the results obtained from previous literatures and researches espouse on resettlement schemes globally and that of the researcher glaringly presupposes that the inculcation of strategic initiatives into any nation's resettlement regimes will invariably decimate the population dynamics of the bottlenecks associated with its socio-cultural domain to an acceptable threshold, thereby curtailing it to the barest minimum as and when due.

\subsection{Recommendations}

With particular reference to the socio-cultural issues associated with resettlement schemes in Ghana and beyond, the under-listed strategies are of immense relevance to its management:

Avoidance or minimization of involuntary resettlement: Firstly, avoidance or minimization of involuntary resettlement through appropriate technical choices will be more appropriate in this regard.

Reconceptualization of resettlement programs: Secondly, if displacement cannot be avoided, resettlement ought to be conceived and executed as a development program, for which a plan ought to be prepared.

Encouragement of community participation: Community participation in planning and implementation ought to be encouraged. Hosts, as well as resettled, ought to be consulted to encourage integration.

Effective compensation packages should be given the needed precedence: Compensation (including land, housing, and infrastructure) ought to be provided to the adversely affected and customary rights should be taken into account.

Adequate valuation of assets: Valuation of assets should be at replacement cost.

Timely transfer of responsibilities: There should be a timely transfer of responsibilities from agencies to resettlers to avoid dependency relationships.

Internalization of resettlement costs: First and foremost, all costs of resettlement need to be internalized within project budgets. These costs need to include the full social costs, which include the loss of non-priced environmental and cultural assets, loss of social cohesion, loss of market access and psychological damage.

Widening of risk analysis: Risk analysis also needs to be broadened beyond the risk to financial and implementing institutions to recognize the risks to all project actors and their distribution

Prioritization of economic sustainability questions: Questions of economic sustainability also need to be taken into account, among them intergenerational equity. This requires that stocks of capital assets be no less in the future than now; capital assets involved in resettlement include the everyday notion of capital, but also the stock of skills and knowledge (human capital) and environmental assets.

Consideration of different kinds of assets' equivalence: The issue of equivalence of different kinds of assets should also be considered.

Adequate data management on potential socio-economic recovery sources: There also needs to be better data on potential sources of socio-economic recovery. This might include a greater analysis of the characteristics of the regional economy and existing economic development policies and initiatives. It might include studies of multiple packages and new possibilities for more remunerative income earning activities, such as ways to add value to various kinds of local products. Both agricultural and forest products can be processed and marketed.

Resettlement democratization: Democratizing resettlement through greater participation should be considered a priority in this perspective. 
Strict adherence to equity, fairness and transparency: The strict adherence to motivational, management, sustainable development models and quality gurus such as Geert Hofstede's Cultural Dimension Theory, Frederick Herzberg's 2 Factor Theory, Total Quality Management (TQM), Balance Score Card (BSC) in addition to Contingency Theory, Human Relation Theory, Latham and Locke Goal Setting Abraham Maslow's Need hierarchy, Reconstruction and Risk Model, Adam Stacy's Equity Theory, Vroom Expectancy Theory of Motivation, Kaoru Ishikawa Tools of Quality, Kaizen Continuous Improvement will inadvertently help a great in this instance.

Effective conflict resolution and grievance strategies: Resettlers and host communities should have affordable and accessible procedures for third-party settlement of disputes arising from resettlement. Grievance mechanisms of that nature should take cognizance of the availability of judicial recourse and community and traditional dispute settlement mechanisms.

Efficient monitoring and evaluation: There should be a monitoring and evaluation (M\&E) mechanism which provides the basis to assess the overall success of the resettlement and the effectiveness of the various processes and measures.

Strict adherence to environmental impact assessment regimes: Environmental impact assessment should be factored into the planning of hydroelectric power project (HEP). The options that can titivate adverse repercussions on individuals and milieu (surrounding) should be considered a nip in the bud. The ideal system should be to make HEP advancement an appropriate strategy in which communal, physical and monetary parameters are all given the requisite precedence. This will undoubtedly provide quite a sizable plethora of economies worldwide with opportunities to develop a governmental infrastructure that combines state, global and indigenous knowledge about unique local conditionalities. This strategic initiative is indispensable in view of the fact that theories/models on sustainable development, including resettlement, traces it lineage from highly developed economies and should be applied while taking cognizance of specific local contexts as a prerequisite tool.

Adherence to effective quality management strategies: The factoring of Six Sigma, Quality Circles, Process Variation as well as the postulates of key quality gurus like Walter Shewhart (development of control charts and quality assurance), W. E. Deming (non-faulty systems/out-of-crisis), Joseph .M. Juran (strategic quality planning), Armand. V. Feigenbaum (concept of total quality control and continuous quality improvements), Kaoru Ishikawa (quality circles, fishbone diagram as well as the emphasis on internal customers), Philip Crosby (cost of poor quality far outweighs cost of preventing poor quality), Genichi Taguchi (emphasis on consistency of performance, decrease variations, quality loss function (QLF), parameter design, etc.) into resettlement regimes (management) of a country scheme of things cannot be underestimated in this perspective.

Creation of resettlement options: Intrinsic to the idea of sustainable development is increasing people's options, as one strategy to increase their sense of well-being and control. Options also offer a way to respond to the diverse needs and interests of displaced and affected populations.

Above all, increasing the availability and utility of economic resources, environmental sustainability (implying equitable access across generations); respect for basic human rights, increasing equity between affected groups and other national groups as well as increasing equity among the different groups within affected populations, increasing local autonomy and control, in addition to improving people's ability to improve their interactions with national institutions will invariably go a long way to turn the table as far as the issues encompassing socio-cultural aspect of resettlement schemes in Ghana and beyond is concerned.

\subsection{Limitations of the Study}

Limitations are matters and occurrences that arise in a study which are out of the researcher's control. They limit the extensity to which a study can go, and sometimes affect the end result and conclusions that can be drawn (Simon \& Goes, 2013). Every study, no matter how well it is conducted and constructed has limitations. The following limitations pertains to the study:

Unwillingness to fill out questionnaires: Put simply, the challenges experienced during the study included some of the participants not filling or completing the questions or some issues being misunderstood, inadequate responses to questionnaires and unexpected occurrences like people going on leave before completing the questionnaire. This was mitigated through constant reminder to the respondents during the period the questionnaires were administered to them. The organizational confidential policy restricted most of the respondents from answering some of the questionnaires. This was considered to be against the organization confidentiality policy to expose the organization confidential matters. 
Finances: As the researcher had a limited budget, it was difficult to administer more questionnaires due to the cost of printing.

Time factor: The researcher could not put any pressure on the participants as some of them saw the exercise to be a time waster and were not prepared to compromise a few minutes to answer the questions. It took a few weeks to get the approval and it was also with difficulty and a lot of resources getting the questionnaire that were given to the staff back, taking cognizance of the busy schedule of staff.

Accuracy of data: While all efforts were made to assure the respondents that the information that was given, would be treated with the strictest of confidentiality, it could happen that the respondents gave normative answers based on what they perceived the answers to be, or what they thought the interviewer wanted to hear.

\section{References}

Abbink, J. (2012). Dam controversies: Contested governance and developmental discourse on the Ethiopian Omo river dam. Social Anthropology, 20(2), 125-144. https://doi.org/10.1111/j.1469-8676.2012.00196.x

Andam, K., Ferrarob, P., Simsc, K. R., Healyd, R., \& Hollande, M. B. (2010). Protected areas reduced poverty in Costa Rica and Thailand. PNAS, 107(22), 9996-10001. https://doi.org/10.1073/pnas.0914177107

Ansar, A., Flyvbjerg, B., Budzier, A., \& Lunn, D. (2014). Should we build more large dams? The actual costs of $\begin{array}{llll}\text { hydropower megaproject development. Energy Policy, } & 69,56 .\end{array}$ https://doi.org/10.1016/j.enpol.2013.10.069

Arthur, J. L. (2016). Living with the Bui dam: implications for community livelihoods. PhD Thesis, Department of Geography, University of Victoria, 1-274.

Asian Development Bank (ADB). (2010). Involuntary resettlement. Retrieved from www.adb.org/documents/policy-involuntary-resettlement

Bartolome, L. J., De Wet, C., Mander, H., \& Nagraj, V. K. (2000). Displacement, resettlement, rehabilitation, reparation and development. Cape Town, South Africa: Thematic Review I.3 prepared as an input to the World Commission on Dams, 2000. Retrieved from http://www.dams.org/kbase/thematic/tr13.htm

Bennett, O., \& McDowell, C. (2012). Displaced: the human cost of development and displacement. Palgrave: Macmillan. https://doi.org/10.1057/9781137074232

Biswas, A. K. (2012). Impacts of large dams: issues, opportunities and constraints. In impacts of large dams: A Global Assessment, 1-18, Berlin: Springer.

BPA. (2011a). Leaflet describing the Bui hydropower project, background and proposed benefits. Accra: Bui Power Authority.

BPA. (2011b). In environmental activities: salvage archaeological. Retrieved from http://www.buipowerauthority.com/sal_arch.htm

BPA. (2011c). In resettlement package. Retrieved from http://www.buipowerauthority.com/res_package.html

BPA. (2015). Bui Power Authority Manual. Retrieved from www.buipower.com

Cave, A., Gao, R. E., Joynes, E., Mgbako, C., \& Mikhailevich, J. (2010). Forced eviction and resettlement in Cambodia: Case studies from Phnom Penh. Washington University Global Studies Law Review, 9, 39.

Cernea, M. (1996). Understanding and preventing impoverishment from displacement: Reflection on the state of knowledge. In McDowell, C. (Ed.), Understanding impoverishment, the consequence of development induced displacement. Berghahn books, Oxford.

Cernea, M. (2003). For a new economics of resettlement: A sociological critique of the compensation principle. International Social Science Journal, 55, 37-47. https://doi.org/10.1111/1468-2451.5501004

Cernea, M. (2004). Impoverishment risk, risk management, and reconstruction: A model of population displacement and resettlement. Paper presented at the UN Symposium on Hydropower and Sustainable Development in support of, and as background to, the Keynote Paper prepared by the same author in the set of sessions of the Symposium devoted to the Social Aspects of Hydropower Development. Beijing, October 27-29 2004. George Washington University, Washington, D.C., USA. Retrieved from http://www.un.org/esa/sustdev/sdissues/energy/op/hydro_cernea_population_resettlement_backgroundpaper .pdf

Cernea, M. M. (1999). The economics of involuntary resettlement: questions and challenges. Washington, D.C. The World Bank. https://doi.org/10.1596/0-8213-3798-X

Cernea, M. M. (2000). Risks, safeguards and reconstruction: a model for population displacement and 
resettlement. In Risks and reconstruction: experiences of resettlers and refugees. M.M. Cernea and C. McDowell, eds. Washington, DC: The World Bank, 11-55. https://doi.org/10.1596/0-8213-4444-7

Cernea, M. M. (2005). Concept and method. Applying the IRR model in Africa to resettlement and poverty. In I. Ohta, \& Y. D. Gebre (Eds.), Displacement risks in Africa. Refugees, resettlers and their host population (pp. 195-258). Kyoto: Kyoto UP.

Cernea, M. M., \& Guggenheim, S. (1993). Anthropological approaches to resettlement: policy, practice, and theory. Boulder, CO: Westview.

Creswell, J. W. (2009). Research design: qualitative, quantitative and mixed methods approaches (3rd ed.). London: Sage Publications, Incorporated.

Creswell, J. W. (2013). Qualitative inquiry and research design: choosing among five approaches (3rd Ed.). London, England: Sage.

De Wet, C. (2000). The experience with dams and resettlement in Africa: dams and development: a new framework for decision-making. World Commission on Dams. Prepared for Thematic Review 1.3: Displacement, resettlement, rehabilitation, reparation and development. Department of Anthropology, Rhodes University, South Africa. Retrieved from http://siteresources.worldbank.org/INTINVRES/214578

De Wet, C. (2004). Why do things so often go wrong in resettlement projects? In A. Pankhurst, \& F. Piguet (Eds.), People, Space and State: Migration, Resettlement and Displacement in Ethiopia. Addis Ababa University, Addis Ababa.

De Wet, C. (2006). Development-induced displacement: problems, policies and people. Berghahn books.

De Wet, C. (2009). Why do things often go wrong in resettlement projects? In A. Pankhurst, \& F. Piguet (Eds.), Moving people in Ethiopia: Development, displacement and the state (pp. 35-48). Boydell and Brewer Ltd.

Ding, C. (2007). Policy and praxis of land acquisition in China. Land Use Policy, 24, 113. https://doi.org/10.1016/j.landusepol.2005.09.002

Downing, T. (1996). Mitigating social impoverishment when people are involuntarily displaced. In C. McDowell (Ed.), Understanding impoverishment: The consequences of development-induced displacement (pp. 33-48). Providence, RI and Oxford: Berghahn.

Dzodzi, N. (2006). Living in the shadow of the large dams: long term responses of downstream and lakeside communities of Ghana's Volta River Project. Leiden: Koninklijke Brill NV.

Earle, T. (1997). How chiefs come to power: the political economy in prehistory. Stanford, CA: Stanford University Press.

Egré, D. (2007). Revised final report - Benefit sharing issues. Compendium on relevant practices - 2nd stage. United Nations Environment Programme. Dams and Development Project. Retrieved October 9, 2012, from http://www.unep.org/dams/files/Compendium/Report_BS.pdf

Environmental Resource Management (ERM). (2007). Resettlement planning framework for the Bui hydropower project. Prepared by the Environmental Resources Management, in association with SGS Environment. Approved and signed by Eamonn Barrett for and on behalf of Environmental Resources Management.

Evrard, O., \& Goudineau, Y. (2004). Planned resettlement: Unexpected migration and cultural trauma in Laso. Development and Change, 35(5), 937-961. https://doi.org/10.1111/j.1467-7660.2004.00387.x

Ferraro, P., Hanauer, M., Katharine, R., \& Sims, K. (2011). Conditions associated with protected area success in

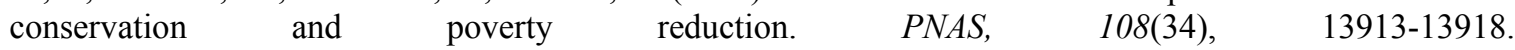
https://doi.org/10.1073/pnas.1011529108

Fratkin, E. (2014). Ethiopia's pastoralist policies: Development, displacement and resettlement. Nomadic Peoples, 18, 94-114. https://doi.org/10.3197/np.2014.180107

Ghana News Agency. (2012, September). Bui Authority resettled affected communities. Ghana News of Sunday, $\begin{array}{lllll}\text { Accra. } & \text { Retrieved } & \text { September } & \text { 2012, } & \text { from }\end{array}$ http://www.ghanaweb.com/GhanaHomePage/NewsArchieve/artikel.php?ID

Gordon, C. (2006). Dams and development in Ghana. Background paper for the multi-stakeholder consultation process for dams' development in Ghana, Volta Basin Research Project, Ghana. Retrieved from http://new.unep.org/dams/files/Country\%20Dialogues/BackgroundStudyGhana.pdf

Gordon, C., \& Amatekpor, J. (1999). The sustainable integrated development of the Volta Basin in Ghana. Accra: University of Ghana. 
Han, S., \& Vu, K. (2009). Land acquisition in transitional Hanoi, Vietnam. Urban Studies, 45, 1097-1117.

International Rivers. (2011). Development-induced displacement: three Gorges dam. Training on the protection of IDPs. Retrieved from http://www.internationalrivers.org/china/three-gorges-dam

International Rivers. (2013). Human impacts of dams. Retrieved July 17, 2014, from http://www.internationalrivers.org/humanimpacts-of-dams

IUCN. (2010). Parks and reserves in Ghana. Gland: IUCN.

Jachmann, H., Blanc, J., Nateg, C., Balangtaa, C., Debrah, E., Damma, F., \& Kipo, A. (2011). Protected area performance and tourism in Ghana. South African Journal of Wildlife Research, 41(1), 95-109. https://doi.org/10.3957/056.041.0112

Kalitsi, E. (2004). Social aspects of hydropower development perspectives and experiences: Hydropower development and resettlement (Ghana). United Nations Symposium on hydropower and sustainable development Beijing International Convention Centre, 27-29 October, 2004. Beijing: United Nations.

Koenig, D. (2001). Toward local development and mitigating impoverishment in development-induced displacement and resettlement. Final report prepared for ESCOR R7644 and the research programme on development-induced displacement and resettlement organized by the Refugee Studies Centre, University of Oxford, 1-101.

Krueger, L. (2009). Protected areas and human displacement: improving the interface between policy and practice. Conservation and Society, 7(1), 21-25. https://doi.org/10.4103/0972-4923.54793

Kyei-Dompreh, F. (2012). Management of VRA resettlement towns: case study of West Kpong resettlement town. CEMBA Thesis, KNUST, 1-92.

Leedy, P. D., \& Ormrod, J. E. (2010). Practical research: planning and design (9th ed.). Upper Saddle River, NJ: Pearson Education Inc.

Lerer, L. B., \& Scudder, T. (1999). Health impacts of large dams. Environmental Impact Assessment Review, 19(2), 113-123. https://doi.org/10.1016/S0195-9255(98)00041-9

Lund, R. (2009). Online Lecture: development-induced displacement and resettlement: An introduction to the concept, magnitude, impacts and dilemmas. Trondheim, Norway: Norwegian University of Science and Technology.

Mahapatra, L. K. (1996). Involuntary displacement in dam projects and the tribal oustees in Orissa. In A. B. Ota, \& A. Agnihotri (Eds.), Involuntary displacement in dam projects (pp. 43-74). New Delhi: Prachi Prakshan.

Marfo, A. (2014). Old Dokokyina residents given 2-week ultimatum to vacate Bui dam site. Retrieved June 12, 2014, from http://www.graphic.com.gh/news/general-news.html

Miine, L. K. (2014). Sustainability of Bui resettlement scheme in Ghana. Master's Thesis. Development Policy and Planning, College of Architecture and Planning, 1-128.

Moore, D. S. (2009). The practice of business statistics: Using data for decisions (2nd ed.). New York: W.H. Freeman and Co.

Oberai, A. S. (1992). An overview of settlement policies and programmes. In P. Dieci, \& C. Viezzoli (Eds.), Resettlement and rural development in research, training and technical assistance in the Beles Valley: Malimo (Italy): CISP.

Ofori-Amanfo, R. (2005). Hippopotamus census in Bui national park. Accra: Ghana Wildlife Division.

Olawepo, R. A. (1997). Resettlement and rural development: the dynamics of rural change in the resettled villages of Jebba Lake Basin (Doctoral Thesis). Department of Geography, University of Ilorin, Nigeria.

Oliver-Smith, A. (1996). Fighting for a place: the policy implications of resistance to development-induced resettlement. In C. McDowell (Ed.), Understanding impoverishment: The consequences of development-induced displacement (pp. 77-97). Providence, RI and Oxford: Berghahn.

Pankhurst. A., \& Piguet, F. (2009). Moving people in Ethiopia: development, displacement and the state. Rochester, NY. James Currey.

Peter, J. (2013). Dam history repeating. Dawson Creek: Infomart.

Polit, D. F., \& Beck, C. T. (2012). Nursing research: generating and assessing evidence for nursing practice. Philadelphia: Wolters Kluwer Health/Lippincott Williams \& Wilkins.

Polit, D. F., \& Hungler, B. P. (1999). Nursing research: principles and methods (6th ed). London: Lippincott 
Williams \& Wilkins.

Raschid-Sally, L., Akoto-Danso, E. K., Kalitsi, E. A. K., Ofori, B. D., \& Koranteng, R. T. (2008). The resettlement experience of Ghana analyzed via case studies of the Akosombo and Kpong dams. Paper presented at the $9^{\text {th }}$ Annual Symposium on Poverty Research in Sri Lanka exploring experiences of resettlement.

Saunders, M., Lewis, P., \& Thornhill, A. (2007). Research methods for business students (4th ed.). Pearson Education Limited. Edinburgh Gate, England, 586.

Scudder, T. (1996). Development-induced impoverishment, resistance and river-basin development. In C. McDowell (Ed.), Understanding impoverishment: the consequences of development-induced displacement (pp. 49-74). Providence, RI and Oxford: Berghahn.

Scudder, T., \& Colson, E. (1982). From welfare to development: a conceptual framework for the analysis of dislocated people. In Involuntary migration and resettlement. In A. Hansen, \& A. Oliver Smith (Eds.), The problems and responses of dislocated people (pp. 267-287). Boulder, CO: Westview.

Simon, M. K., \& Goes, J. (2013). Dissertations and scholarly research: recipe for success. Seattle, WA: Dissertation Success LLC, 1-3. Retrieved from www.dissertationrecipes.com

Sutcliffe, C. (2009). Interviews with people to be affected by Bui dam: a field report. Retrieved from http://www.internationalrivers.org/files/Bui\%20Field\%20Report.pdf

Syagga, P., \& Olima, W. (1996). The impact of compulsory land acquisition on displaced. Habitat International, 20, 61-75. https://doi.org/10.1016/0197-3975(95)00034-8

Szafram, R. (2012). Answering questions with statistics. Los Angeles, CA: Sage.

Tadesse, A. (2009). The dynamics of resettlement with reference to the Ethiopian experience. Kimmage Development Studies Centre (KDSC), 1-24.

Tain District Assembly. (2012). Tain district. Retrieved September 28, 2012, from http://ghanadistricts.com/districts1on1/tain/

The World Bank. (2004). Involuntary resettlement sourcebook. Washington: The International Bank for Reconstruction and Development. The World Bank.

Turton, D. (2009). Refugees and forced resettlers. In A. Pankhurst, \& F. Piguet (Eds.), Moving people in Ethiopia: Development, displacement and the state (pp. 23-34). Boydell and Brewer Ltd.

Ty, P. H., Van Westen, A. C., \& Zoomers, A. (2013). Compensation and resettlement policies after compulsory land acquisition for hydropower development in Vietnam. Policy and Practice. Land, 2, 678-704. https://doi.org/10.3390/land2040678

UNDP. (2011). Towards human resilience: sustaining MDG progress in an age of economic uncertainty. New York: UNDP.

UNHCR. (2011). Resettlement handbook. Switzerland United Nations High Commissioner for Refugees.

United Nations High Commission for Refugees (UNHCR). (2004). Progress report on resettlement. Retrieved May 13, 2014, from http//wwwUnhcr.Org/40c706964.html

WCD. (2000). Dam and development: a new framework for decision-making. The report of the World Commission on Dam. London: Earth can.

Wolde-Selassie, A. (2009). Social impact of resettlement in the Beles Valley. In A. Pankhurst, \& F. Pigeut (Eds.), Moving people in Ethiopia, development displacement and the state. Eastern Africa Series: Addis Ababa.

Yates, J. S. (2004). Doing social science research. London. Sage Publications.

Yntiso, G. (2003). Resettlement and the unnoticed losers: Impoverishment Disasters among the Gumuz in Ethiopia. Human Organization, 62(1), 50-61. https://doi.org/10.17730/humo.62.1.4ava5ykea9p0vk10

\section{Copyrights}

Copyright for this article is retained by the author(s), with first publication rights granted to the journal.

This is an open-access article distributed under the terms and conditions of the Creative Commons Attribution license (http://creativecommons.org/licenses/by/4.0/). 